\title{
The role of microorganisms in the formation of a stalactite in Botovskaya Cave, Siberia - paleoenvironmental implications
}

\author{
M. Pacton ${ }^{1, *}$, S. F. M. Breitenbach ${ }^{1}$, F. A. Lechleitner ${ }^{1}$, A. Vaks $^{2}$, C. Rollion-Bard ${ }^{3}$, O. S. Gutareva ${ }^{4}$, A. V. Osintcev ${ }^{5}$, \\ and C. Vasconcelos ${ }^{1}$ \\ ${ }^{1}$ Geological Institute, ETH Zurich, Sonneggstrasse 5, 8092 Zurich, Switzerland \\ ${ }^{2}$ Department of Earth Sciences, University of Oxford, South Parks Road, Oxford OX1 3AN, UK \\ ${ }^{3}$ Centre de Recherches Pétrographiques et Géochimiques, UMR 7358, Université de Lorraine, 54500 Vandoeuvre-lès-Nancy, \\ France \\ ${ }^{4}$ Institute of the Earth's Crust, Russian Academy of Sciences, Siberian Branch, 128 Lermontova Street, Irkutsk 664033, \\ Russia \\ ${ }^{5}$ Arabica Speleological Club, Mamin-Sibiryak Street, P.O. Box 350, Irkutsk 554082, Russia \\ *now at: Laboratoire de Géologie de Lyon : Terre, Planètes, Environnement Campus de la Doua, Universite Lyon 12 Rue \\ Raphael Dubois, 69622 Villeurbanne Cedex, France
}

Correspondence to: M. Pacton (muriel.pacton@univ-lyon1.fr)

Received: 20 March 2013 - Published in Biogeosciences Discuss.: 8 April 2013

Revised: 25 July 2013 - Accepted: 15 August 2013 - Published: 27 September 2013

\begin{abstract}
Calcitic speleothems in caves can form through abiogenic or biogenic processes, or through a combination of both. Many issues conspire to make the assessment of biogenicity difficult, especially when focusing on old speleothem deposits. This study reports on a multiproxy analysis of a Siberian stalactite, combining high-resolution microscopy, isotope geochemistry and microbially enhanced mineral precipitation laboratory experiments.

The contact between growth layers in a stalactite exhibits a biogenic isotopic signature; coupled with morphological evidence, this supports a microbial origin of calcite crystals. SIMS $\delta^{13} \mathrm{C}$ data suggest that microbially mediated speleothem formation occurred repeatedly at short intervals before abiotic precipitation took over. The studied stalactite also contains iron and manganese oxides that have been mediated by microbial activity through extracellular polymeric substance (EPS)-influenced organomineralization processes. The latter reflect paleoenvironmental changes that occurred more than $500000 \mathrm{yr}$ ago, possibly related to the presence of a peat bog above the cave at that time.

Microbial activity can initiate calcite deposition in the aphotic zone of caves before inorganic precipitation of speleothem carbonates. This study highlights the importance of microbially induced fractionation that can result in large
\end{abstract}

negative $\delta^{13} \mathrm{C}$ excursions. The microscale biogeochemical processes imply that microbial activity has only negligible effects on the bulk $\delta^{13} \mathrm{C}$ signature in speleothems, which is more strongly affected by $\mathrm{CO}_{2}$ degassing and the host rock signature.

\section{Introduction}

The growth of speleothems such as stalactites and stalagmites through the precipitation of calcite has commonly been viewed as an abiogenic process (e.g., Kendall and Broughton, 1978; Broughton, 1983a, b, c). However, there is a growing body of research suggesting that microbes may play an important role in carbonate precipitation during speleothem growth (e.g., Jones and Motyka, 1987; Northup and Lavoie, 2001; Baskar et al., 2005, 2006; Mulec et al., 2007; Jones, 2010). In caves, a variety of precipitation and dissolution processes results in the deposition of carbonate speleothems, silicates, iron and manganese oxides, sulfur compounds, and nitrates, but also in the breakdown of limestone host rock. Cave microbes mediate a wide range of destructive and constructive processes that collectively can influence the growth of speleothems and their internal crystal 
fabric (Jones, 2010). Constructive processes include microbe calcification, trapping and binding by filamentous microbes, and/or mineral precipitation (Cañaveras et al., 2001; Jones, 2001). Destructive processes include microbially influenced corrosion or dissolution of mineral surfaces that can occur through mechanical attack, secretion of exoenzymes, organic and mineral acids (e.g., sulfuric acid), and a variety of other mechanisms (for a summary please refer to Sand, 1997). Of particular interest in cave dissolution processes are reactions involving iron-, sulfur-, and manganese-oxidizing bacteria (Northup and Lavoie, 2001). Iron oxides and hydroxides are most often observed as coatings or crusts and as powder on clastic cave walls, but they also exist as typical speleothems such as stalactites (e.g., Caldwell and Caldwell, 1980; Jones and Motyka, 1987). Several descriptive studies have established the association of bacteria with iron deposits in caves, but experimental evidence for an active microbial role in the formation of iron deposits in caves is still lacking (Northup and Lavoie, 2001).

With regard to flora and fauna, caves are usually divided into two segments: (i) a twilight zone and (ii) an aphotic zone characterized by no light and few microbes (Jones, 2010). In this study we focus on a stalactite found in the aphotic zone. The sample contains mainly calcite and ferromanganese oxides, which is unusual in this continental setting as they are widely encountered in warm environments (e.g., Spilde et al., 2005). The presence of microbes does not automatically imply that they played a role in the formation of the surrounding minerals, because they may simply have been buried during mineral precipitation (Polyak and Cokendolpher, 1992; Forti, 2001). Assessment of the exact role that the microbes played in the mineral precipitation is usually considered impossible to make (Jones, 2010). However, by combining microscopical and geochemical evidence at a high spatial resolution, we aim to constrain precisely the role of microbes in stalactite formation in this cave. Calcite $\delta^{13} \mathrm{C}$ has been interpreted as reflecting surface vegetation changes (C3 vs. C4: Brook et al., 1990; Dorale et al., 1992; Bar-Matthews et al., 1997; Hou et al., 2003; Denniston et al., 2007), although more recent studies point to cave air ventilation as a major influence (Tremaine et al., 2011). It has been demonstrated that degassing of $\mathrm{CO}_{2}$ from the dripwater controls the rate of calcite precipitation (Mickler et al., 2004; Spötl et al., 2005; Bourges et al., 2006; Baldini et al., 2008; Kowalczk and Froelich, 2010), as well as the isotopic composition of dripwater and subsequent calcite (Mattey et al., 2008; Mühlinghaus et al. 2007, 2009; Oster et al., 2010; Frisia et al., 2011; Lambert and Aharon, 2011). These studies show that if carefully evaluated $-\delta^{13} \mathrm{C}$ can be used as a paleoclimatic indicator. However, the potential impact of microbial activity on carbon isotope fractionation is usually overlooked in paleoclimate studies. We aim to investigate this impact in detail in the current work.

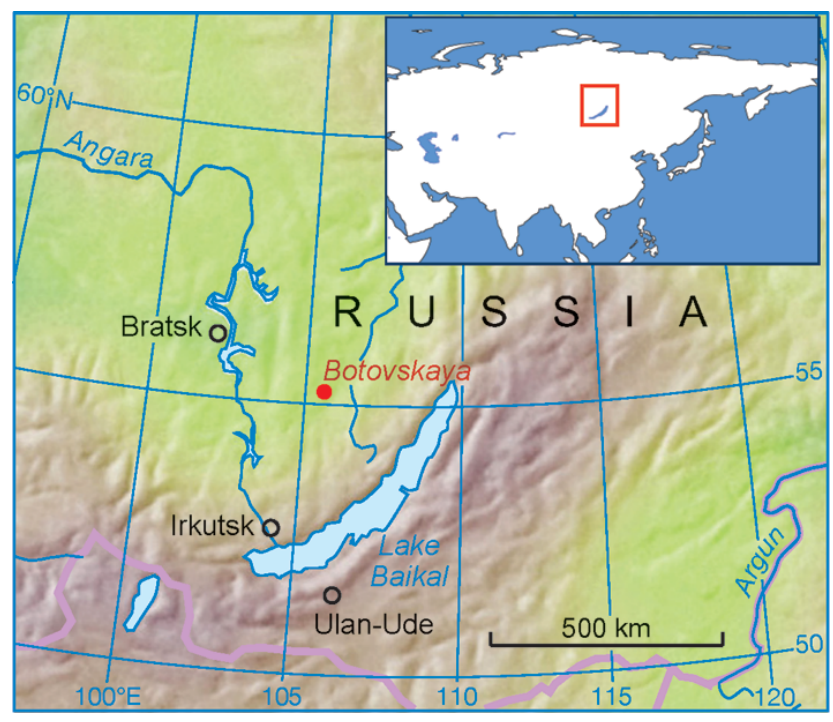

Fig. 1. Map of Siberia, showing the location of Botovskaya Cave.

\section{Study site}

Botovskaya Cave is located in Siberia $\left(55^{\circ} 17^{\prime} 59^{\prime \prime} \mathrm{N}\right.$, $105^{\circ} 19^{\prime} 46^{\prime \prime}$ E, $750 \mathrm{~m}$ above sea level) (Fig. 1 and Fig. S3 in Vaks et al., 2013), and developed as a $>68 \mathrm{~km}$-long horizontal maze of passages along tectonic fissures in a 6 to $12 \mathrm{~m}$ thick Lower Ordovician limestone layer which is sandwiched between marine sandstone and argillite (Filippov, 2000).

The depth of the cave is $40-130 \mathrm{~m}$ below the surface. Beyond a few meters from the small entrances, the light intensity level in the cave is zero. Its passages are characterized by massive clay infillings. The cave is located in discontinuous permafrost, as evident from massive cave ice bodies with $<0^{\circ} \mathrm{C}$ temperatures in the western part of the cave. Microclimatic monitoring reveals that cave air temperature varies only slightly, from just below $0{ }^{\circ} \mathrm{C}$ in the cold zones to 1.6$1.9^{\circ} \mathrm{C}$ in its warmest parts (see Fig. S4 in Vaks et al., 2013). The eastern cave section is the only area where water seepage occurs and speleothems grow today (Vaks et al., 2013). Sample SB-p6915 was collected several hundred meters from the nearest entrance, in the wet and aphotic zone.

The region surrounding the cave is covered by taiga forest and receives ca. $400 \mathrm{~mm}$ annual precipitation. Mean annual surface air temperature is $-2.8^{\circ} \mathrm{C}$, ranging from +35 to $-40^{\circ} \mathrm{C}$.

\section{Methods}

\subsection{Samples}

For this study we use subsamples from stalactite SB-p6915, which is asymetrically shaped and has a diameter of 3.5$4 \mathrm{~cm}$. The sample was found in 2001, more than $1 \mathrm{~km}$ deep inside Botovskaya Cave (Supplement Fig. 1), and consists 


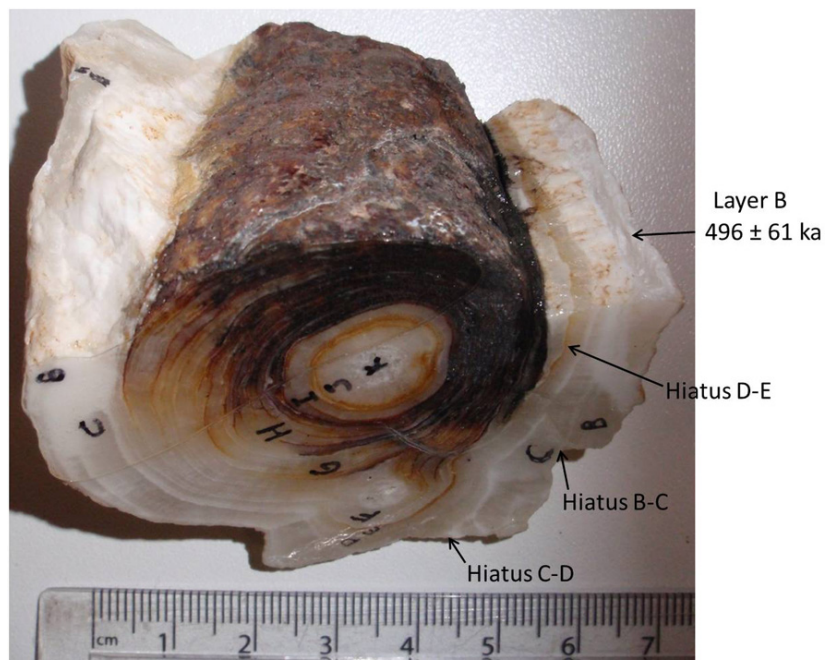

Fig. 2. Location of the drilling trench of the stalactite from Botovskaya Cave at Layer B (upper arrow), where the sample for UTh dating was taken. Note the asymmetric distribution of ferromanganese oxides in the stalactite. At least 2 hiatuses (marked by arrows) divide between Layer B and Hiatus D-E, where the youngest microbial presence can be seen as a thin dark-colored layer.

of a ca. $15 \mathrm{~mm}$-thick white calcite core, surrounded by asymetric dark brown-black layers of a total thickness of 10 $16 \mathrm{~mm}$, which then give place to another white calcite layer of ca. $10 \mathrm{~mm}$ thickness (Fig. 2). The change from the white core to the dark layers is abrupt, with a precursory event that deposited a brown ring about $2 \mathrm{~mm}$ closer to the stalactite's center. The dark layers are compact on one side, but are intercalated with white calcite on the opposite side, where the dark rings fade until they are interrupted. The dark-colored crusts display corrosion surfaces, as they are characterized by an irregular surface topography. The alternating white and dark layers show asymmetric stalactite growth that is likely the result of preferential water flow down one side. An asymmetric growth due to cave wind is unlikely because multiple expeditions at different seasons never observed any cave air current in this (as well as many other) sections of Botovskaya Cave. The latter is most likely due to the location of the stalactite more than $1 \mathrm{~km}$ from the nearest opening and in eliminating any possibility of significant air flows (Supplement Fig. 1). The shallow passages also prohibit the development of vertical airflow, as passages most often have dimensions of 30-100 cm in width and 40-200 cm in height.

Dripwater was collected in February 2011 close to stalactite SB-p6915 in Botovskaya Cave. The samples were collected using sterilized glass bottles and plastic tubes, and were stored refrigerated and maintained at $4{ }^{\circ} \mathrm{C}$ until shipping to ETH Zurich.

\subsection{Mineralogy}

For X-ray diffraction analyses (XRD), samples were ground to a fine powder in an agate mortar. Samples were deposited on a silicon wafer in a plastic sample holder. We employed a Bruker AXS D8 Advance instrument at ETH Zurich, equipped with a scintillation counter and automatic sampler rotating the sample.

\subsection{Microscopy}

The laminae observed in stalactite SB-p6915 were studied by scanning electron microscopy (SEM) on polished and platinum-coated thin sections, using a Zeiss Supra 50 VP SEM at the University of Zurich, Switzerland. Semiquantitative elemental analyses of micron-sized spots were obtained using an energy dispersive X-ray spectrometer (EDS; EDAX, University of Zurich, Switzerland) during SEM observations.

\subsection{Isotope analysis}

In situ, spatially highly resolved carbon and oxygen isotope composition was determined using a Cameca IMS 1270 ion microprobe at the CRPG-CNRS, Nancy, France, following the methodology outlined in Rollion-Bard et al. (2007). A primary $\mathrm{Cs}^{+}$beam of $10 \mathrm{nA}$ intensity was focused on spot size of ca. $20 \mu \mathrm{m}$. The normal incidence electron gun was used to compensate for sample charging during analysis. Measurements of carbon and oxygen isotope ratios were conducted in multicollection mode, using one off-axis Faraday cup ( $\left.\mathrm{L}^{\prime} 2\right)$ and the central electron multiplier, and two offaxis Faraday cups ( $\mathrm{L}^{\prime} 2$ and $\left.\mathrm{H} 1\right)$, respectively. A liquid nitrogen cold-trap was used to lower the gas pressure in the specimen chamber and then to ensure the stability of the measurements. The instrumental mass fractionations (IMF) were determined for reference materials of calcite, dolomite and magnesite to take the effect of the magnesium content on the IMF into account for oxygen isotope measurements, as described in Rollion-Bard and Marin-Carbonne (2011). No such effect was detected for carbon isotope analyses. The typical acquisition time was $3 \mathrm{~s}$ during 40 cycles for carbon isotope compositions and 25 cycles for $\delta^{18} \mathrm{O}$ analyses. Prior to each analysis, the following automated procedure was performed: (1) secondary ion beam centering within the field aperture by adjusting the transfer lens deflector voltages, and (2) magnetic field scanning and peak centering. This procedure leads to an internal precision $(2 \sigma)$ of better than $0.2 \%$ o for $\delta^{13} \mathrm{C}$ and an external reproducibility $(1 \sigma)$ of ca. $0.5 \%$, based on repeated analyses of reference materials, as well as an internal precision of better than $0.1 \% o$ and an external reproducibilty of $\approx 0.3 \%$ ofor $\delta^{18} \mathrm{O}$.

For comparison, 102 carbonate samples were milled across the same sampling trench using a digitally controlled micromill $\left(\right.$ Sherline ${ }^{\circledR}$ ) at $50 \mu \mathrm{m}$ increments parallel to the 
Table 1. U-Th dating results for the SB-6915-B stalactite layer (Vaks et al., 2013). The corrected values are shown in the 3rd and 4th rows.

\begin{tabular}{|c|c|c|c|c|c|c|c|c|c|c|c|}
\hline Sample & ${ }^{238} \mathrm{U}(\mathrm{ppm})$ & ${ }^{232} \mathrm{Th}(\mathrm{ppb})$ & $\left({ }^{230} \mathrm{Th} /{ }^{232} \mathrm{Th}\right)$ & $\left({ }^{232} \mathrm{Th} /{ }^{238} \mathrm{U}\right)$ & $2 \sigma$ abs & $\begin{array}{l}\left({ }^{230} \mathrm{Th} /{ }^{238} \mathrm{U}\right) \\
1.00023\end{array}$ & $\begin{array}{l}2 \sigma \text { abs } \\
0.00304\end{array}$ & $\begin{array}{l}\left({ }^{234} \mathrm{U} /{ }^{238} \mathrm{U}\right) \\
1.00772\end{array}$ & $\begin{array}{l}2 \sigma \text { abs } \\
0.00278\end{array}$ & $\begin{array}{l}\text { Raw Age (ka BP) } \\
496\end{array}$ & $\begin{array}{l}2 \sigma \\
60\end{array}$ \\
\hline SB-p6915-B & 3.51 & 1.02 & 10241 & $9.54 \times 10^{-5}$ & $9.15 \times 10^{-7}$ & $\begin{array}{l}\left({ }^{230} \mathrm{Th} /{ }^{238} \mathrm{U}\right) \text { corr. } \\
1.00023\end{array}$ & $\begin{array}{l}2 \sigma \text { abs } \\
0.00304\end{array}$ & $\begin{array}{l}\left({ }^{234} \mathrm{U} /{ }^{238} \mathrm{U}\right) \text { corr. } \\
1.00772\end{array}$ & $\begin{array}{l}2 \sigma \text { abs } \\
0.00278\end{array}$ & $\begin{array}{l}\text { Corr. Age (ka BP) } \\
496\end{array}$ & $\begin{array}{l}2 \sigma \\
61\end{array}$ \\
\hline
\end{tabular}

growth axis (perpendicular to the crack observed in Fig. 8). The milled powder was measured on a Gasbench II coupled to a Delta V Plus (Thermo Fisher Scientific) mass spectrometer at ETH Zurich. Analytical details can be found in Breitenbach and Bernasconi (2011). The external standard deviation (1) for both isotopes was better than $0.07 \%$. All values are expressed in permil and referenced according to the Vienna Pee Dee Belemnite (VPDB) standard.

\subsection{Dating}

Stalactite SB-p6915 has been dated at Oxford University using the U-Th method (Vaks et al., 2013). For U-Th dating, $132 \mathrm{mg}$ of calcite were taken from the outer rim (Layer B in Fig. 2). Details of the dating procedure are given in the Supplementary Online Materials of Vaks et al. (2013).

\subsection{Laboratory iron-oxide precipitation experiments}

Biofilms were cultured from water samples collected in the cave. The biofilms had been produced from a microbial mat from Lagoa Vermelha, Brazil (Vasconcelos et al., 1995) under stress-controlled conditions, i.e., hypersalinity, in order to produce a significant amount of extracellular polymeric substances (EPS). Prior to the iron experiments, the biofilm was analyzed using SEM, TEM (embedding in Epoxy and cut into ultrathin sections) and XRD in order to validate the absence of any mineral phases (carbonates, iron oxides, amorphous $\mathrm{Mg}-\mathrm{Si}$ phases, etc.) and the abundance of microbes. Transmission electron microscopy data indicate a complete absence of permineralization within EPS and very few bacteria. The abundance of EPS over isolated microorganisms is supported by DAPI-staining (very few fluorescent bacteria) and Gram coloration, suggesting that photosynthetic organisms were unlikely to have played a role in mineral formation. Moreover, TEM examinations of bacteria show cell disruptions with loss of intracellular materials, which would suggest that they are dying (e.g., Diaz-Visurraga et al., 2010). Based on the TEM and DAPI-staining results, we exclude light-favored metabolically driven iron oxide formation. Although the composition and quantity of the EPS vary depending on the type of microorganism and the different environmental conditions under which the biofilms are cultured, this does not alter their ability to bind metal ions from solutions (Decho, 1990; Santschi et al., 1998). Biofilms were cultured from dripwater samples in $125 \mathrm{ml}$ Erlenmeyer flasks at room temperature $\left(\sim 20^{\circ} \mathrm{C}\right)$ and in the presence of sunlight. Precipitation experiments were performed to eval- uate the role that EPS may play in precipitating iron oxides under controlled laboratory conditions. The liquid medium was prepared as follows: $0.5 \mathrm{~g} \mathrm{Fe}\left(\mathrm{NH}_{4}\right)_{2}\left(\mathrm{SO}_{4}\right)_{2} \times 6 \mathrm{H}_{2} \mathrm{O}$ and $10 \mathrm{mg} \mathrm{FeCl}{ }_{3} \times 6 \mathrm{H}_{2} \mathrm{O}$ were added to one liter of $0.2 \mu \mathrm{m}$ filtered dripwater from the stalactite. Erlenmeyer flasks containing $100 \mathrm{~mL}$ of the liquid were inoculated with biofilms (mm-scale thickness). Abiotic "blank" samples containing only the liquid medium were prepared as controls. Plastic push caps were placed on top of each test tube to prevent contamination and minimize evaporation.

Cultures and controls were incubated at room temperature in the presence of sunlight for three weeks. Biofilms were examined using transmitted light microscopy to determine the presence of precipitates. Samples of biofilms and secondary mineral precipitates were collected using a sterile spatula and examined using SEM. Precipitates were collected and analyzed for their mineralogical composition using XRD.

\section{Results}

\subsection{Dating results and approximate age of microbial deposition}

The U-Th age of Layer B in stalactite SB-6915 has been determined as $496 \pm 61 \mathrm{ka}$ BP (before present, i.e., $1950 \mathrm{AD}$ ) (Fig. 2, Table 1). According to Vaks et al. (2013), Quaternary speleothem growth in Botovskaya Cave occurred only during the warmest episodes of interglacial periods when permafrost above the cave thawed. The dated layer corresponds to interglacial marine isotope stage (MIS) 13. If the speleothem growth during periods older than $500 \mathrm{ka}$ followed the same pattern as during the younger periods, the calcite layers represent interglacial speleothem deposition, whereas thin white and brown layers represent hiatuses, i.e., interruptions in speleothem deposition associated with colder permafrost conditions (Vaks et al., 2013). Each hiatus thus represents a surface of the stalactite during a period of growth interruption (most likely permafrost conditions). The hiatus between Layers $E$ and $D$ is the last speleothem surface on which a microbial community was observed. Two calcite layers and two hiatuses separate Layer B and the last period where microbial occurrence was observed (Fig. 2), suggesting that it occurred at least two glacial-interglacial cycles before MIS-13. Although only tentative, this line of argument may place the minimum age of the end of microbial growth on the stalactite surface at the beginning of interglacial MIS- 

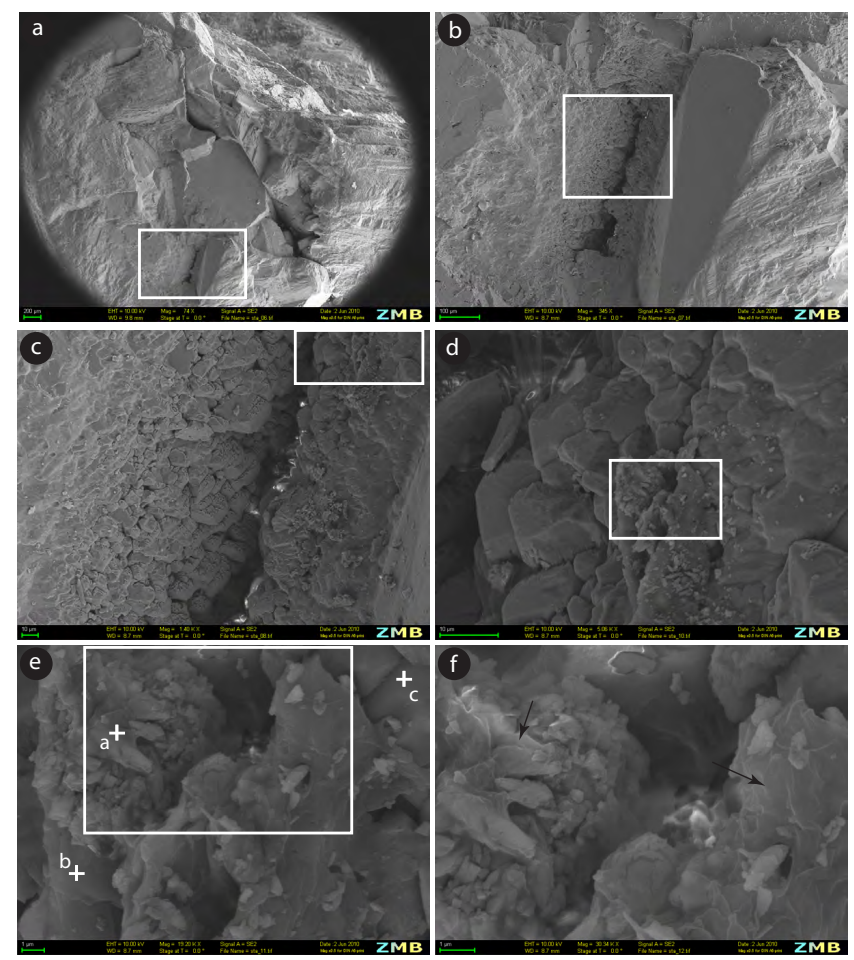

Fig. 3. Secondary electron images of the surface of the stalactite: (a, c) the contacts between layers show the terminations of columnar crystals characterized by cavities and irregular crystals; (d, f) irregular small calcite crystals are covered by EPS-like structures showing sheet morphologies (arrows).

17, about $700 \mathrm{ka}$ BP. Detailed U-Pb dating could possibly refine this provisional chronology.

\subsection{Texture and morphology of the stalactite}

\subsubsection{White laminae}

The stalactite is characterized by an alternation of thickly laminated columnar crystals and thinner layers. Trigonal prismatic calcite crystals, forming columnar horizons up to $1 \mathrm{~mm}$ long and $0.2 \mathrm{~mm}$ wide, are widely distributed. The contacts between layers are characterized by cavities and irregular crystals at the terminations of the columnar crystals (Fig. 3a-d). The cavities are made by small calcite crystals, which are covered by EPS-like structures showing sheet morphologies (Fig. 3e, f). Elemental analyses confirm the organic composition, shown by the higher carbon peak (Fig. 4a), compared with that of the surrounding calcite crystals (Fig. 4b). This biofilm is locally composed of Mg and $\mathrm{Si}$ (Fig. 4c). Similar microbial structures on the calcite have been observed in other speleothems from the same cave. Close to columnar calcite, smaller calcite rhombs exhibit dissolution features (Fig. 5a-d). The latter are sometimes covered by aluminosilicates (Fig. 5e, f). Microbes are associated with these smaller rhombs (Fig. 6a-d) and are confirmed

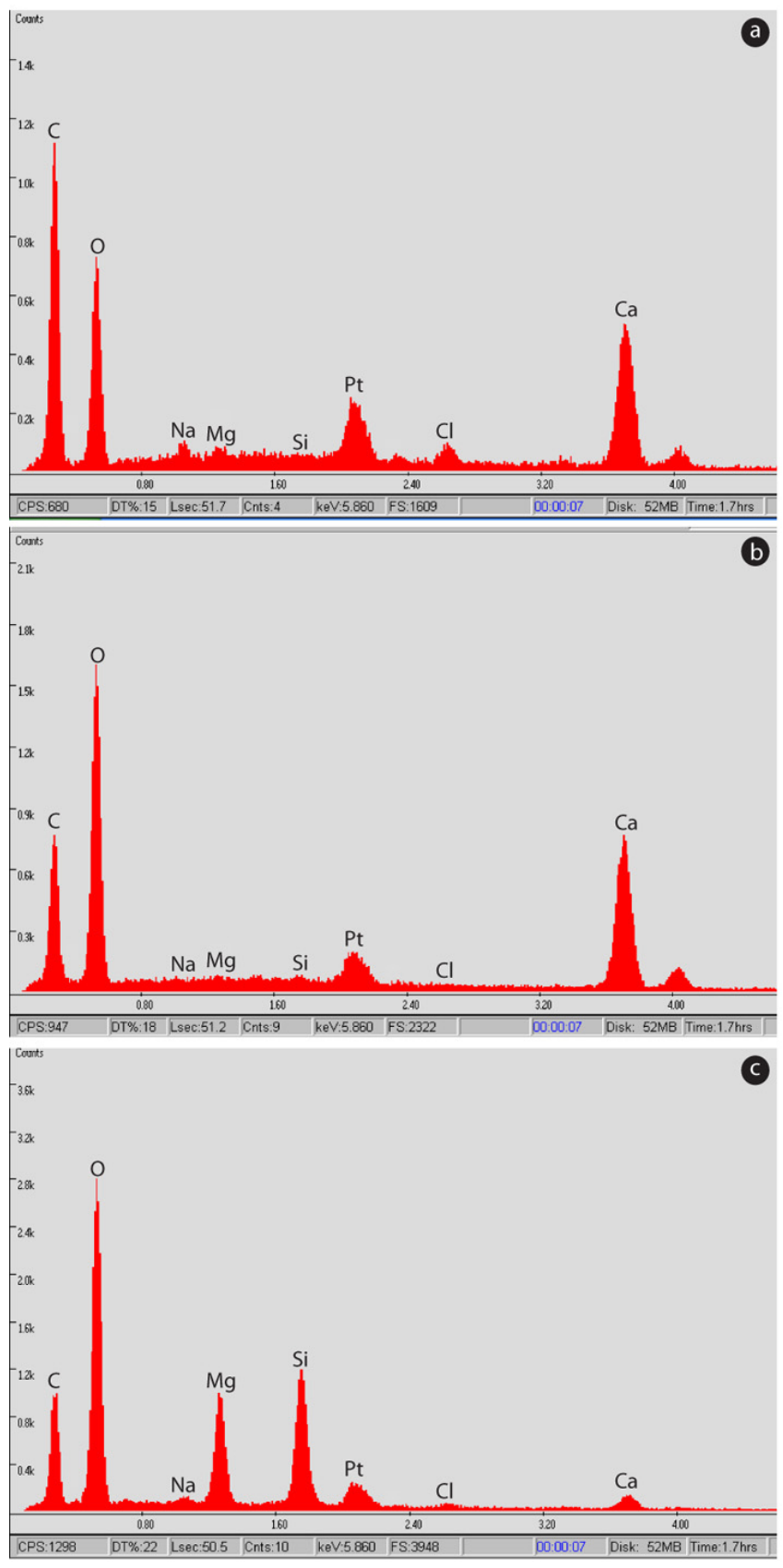

Fig. 4. Elemental analyses using EDAX in the SEM area (Fig. 9f): (a) organic composition of the biofilm as shown by the high $\mathrm{C}$ peak; (b) surrounding calcite; (c) biofilm is locally permineralized as $\mathrm{Mg}$ Si-O.

by the occurrence of filaments (Fig. 6c) and EPS (Fig. 6d). Smaller rhombs are locally covered by a thin biofilm made of low-magnesium calcite (Fig. 6e, f).

The carbonates are identified as calcite by XRD spectra (Fig. 7a). SEM and EDX analyses confirm the presence of this mineral and also reveal the presence of amorphous $\mathrm{Mg}-\mathrm{Si}\left({ }_{\mathrm{am}} \mathrm{Mg}-\mathrm{Si}\right)$ phases that were not detected by XRD 

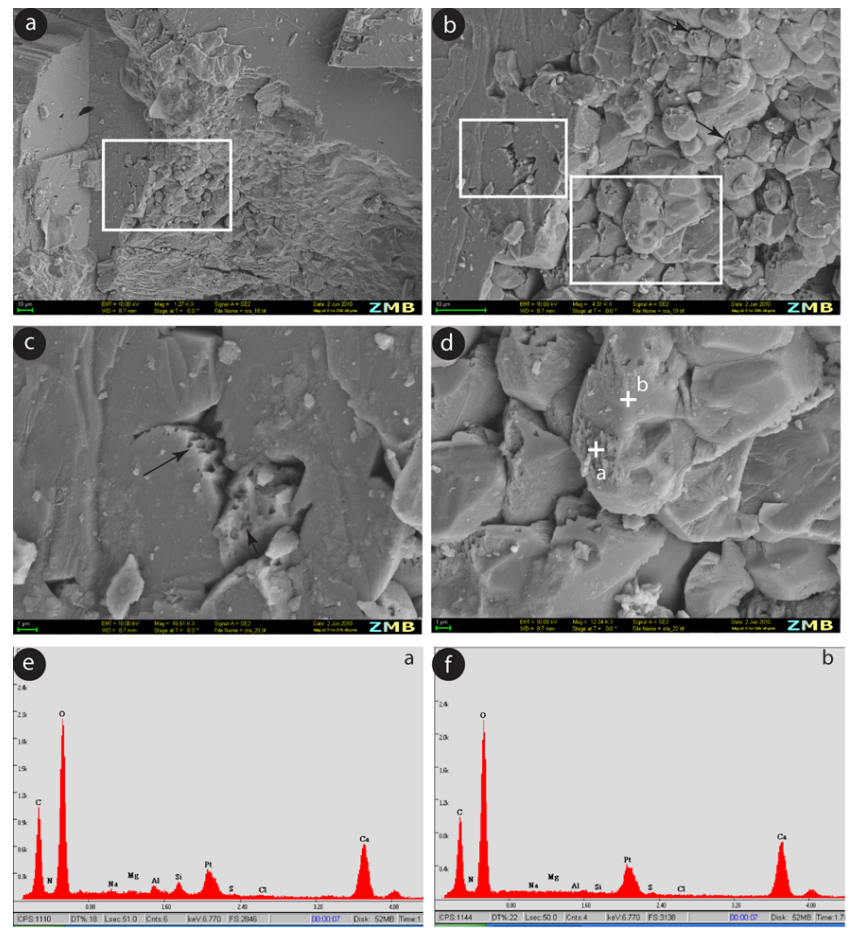

Fig. 5. Secondary electron images of the surface of the stalactite: (a-c) dissolution features (arrows) of the small calcite rhombs close to columnar calcite; (d) they are sometimes covered by a film; (e, f) elemental analyses of this film show that it is composed of aluminosilicates on the top of calcite rhombs.

analysis. The thickly laminated, columnar calcite crystals have SIMS $\delta^{13} \mathrm{C}$ values between $-1.27 \%$ and $+1.06 \%$, which are in the same range as obtained by the isotope ratio mass spectrometry (IRMS) $(-2.3 \%$ to $+2.2 \%$ ), and observed in several other stalagmites from Botovskaya Cave (Supplement Table 1, Breitenbach, 2004). The contacts at the different cracks, which are characterized by thinner layers, display very negative SIMS $\delta^{13} \mathrm{C}$ values ranging from -5.27 to $-13.19 \%$ (Fig. 8 and Supplement Figs. 2-3). This strong depletion is not found in the IRMS data, where $\delta^{13} \mathrm{C}$ values remain in the range from 0 to $-2 \%$ (Fig. 9). The crack however is visible as carbon and oxygen shifts towards more negative values. The IRMS $\delta^{13} \mathrm{C}$ decrease has to be relativized, since shifts of this magnitude occur throughout the analyzed section.

SIMS $\delta^{18} \mathrm{O}$ also reflects a ca. three permil depletion of -11.9 to $-15 \%$ around the crack, while this is less significant in the IRMS $\delta^{18} \mathrm{O}$ data: here less depleted (1.5 to $2 \%$ compared to before the crack) values are observed. Over the entire IRMS profile, $\delta^{18} \mathrm{O}$ varies from -12 to $-14.5 \%$ o (Fig. 9).

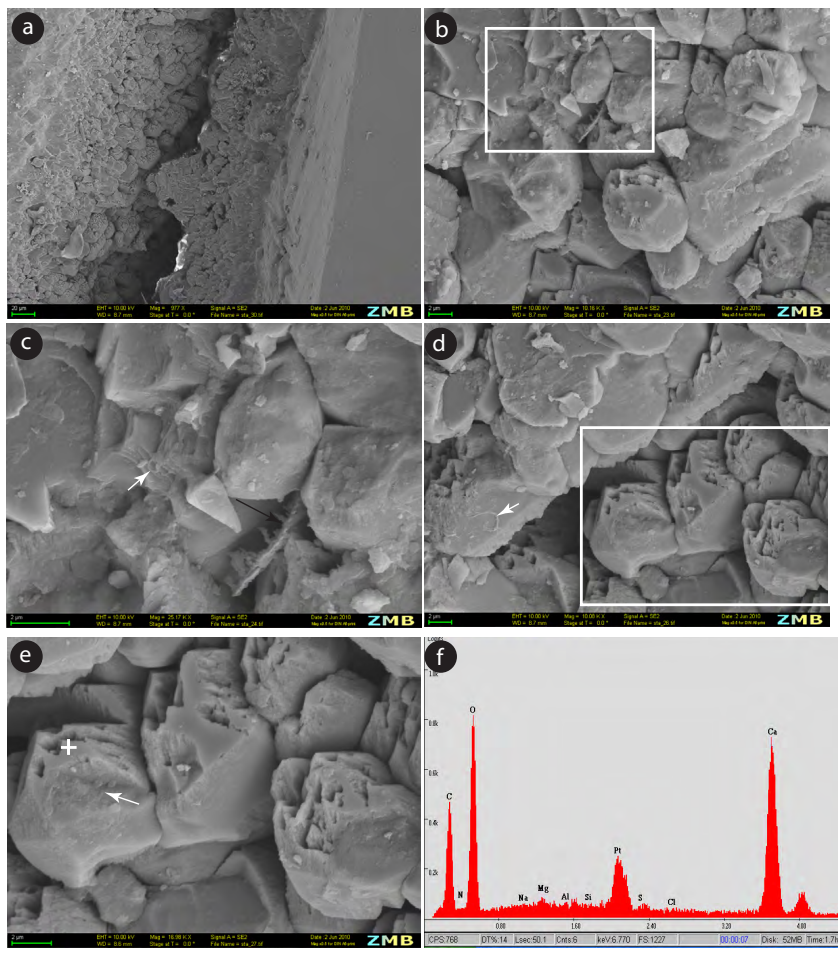

Fig. 6. Secondary electron images of the calcite rhombs in the cavities: (a-d) microbes are widely distributed as filaments (black arrow) and EPS (white arrows). (e) Smaller rhoms are locally covered by a thin biofilm; (f) elemental analysis of the biofilm showing that it is made of low-magnesium calcite.

\subsubsection{Dark-brown crusts}

Stalactite SB-p6915 shows multiple dark brown to black crusts (Fig. 2). XRD analyses detected only calcite, which is poorly defined in the diffractogram, indicating that all the crusts had a low crystallinity (Fig. 7b).

SEM analyses reveal an abundance of predominantly spherical bodies with sizes ranging from a few microns to $20 \mu \mathrm{m}$ (Fig. 10a-d). These are composed of iron oxides that cover depressions between calcite crystals (Fig. 10a) and can be associated with $\mathrm{Mg}$-Si phases (Fig. 10). They are composed of acicular needles that are radially arranged, thus forming coccoid bodies (Fig. 10d, e). These bodies display a close association with EPS, as the needles are located within or below EPS (Fig. 10c-e).

Microborings are present on the surface of calcite crystals. These are characterized by open borings and resin casts: open borings consist of solitary spherical cells of an average diam-

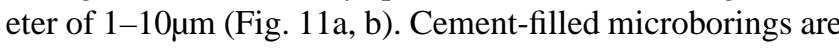
occasionally visible, and consist of Fe-Si phases and lowmagnesium calcite cast precipitates (Fig. 11c, d). The microborings are covered by Fe-Si-Mn crusts composed of nanofilaments, which form flakes (Fig. 11e, f). Close to depressions, microborings are corroded by iron oxides (Fig. 12a, b). The latter are characterized by fibrous radial structures, which are 


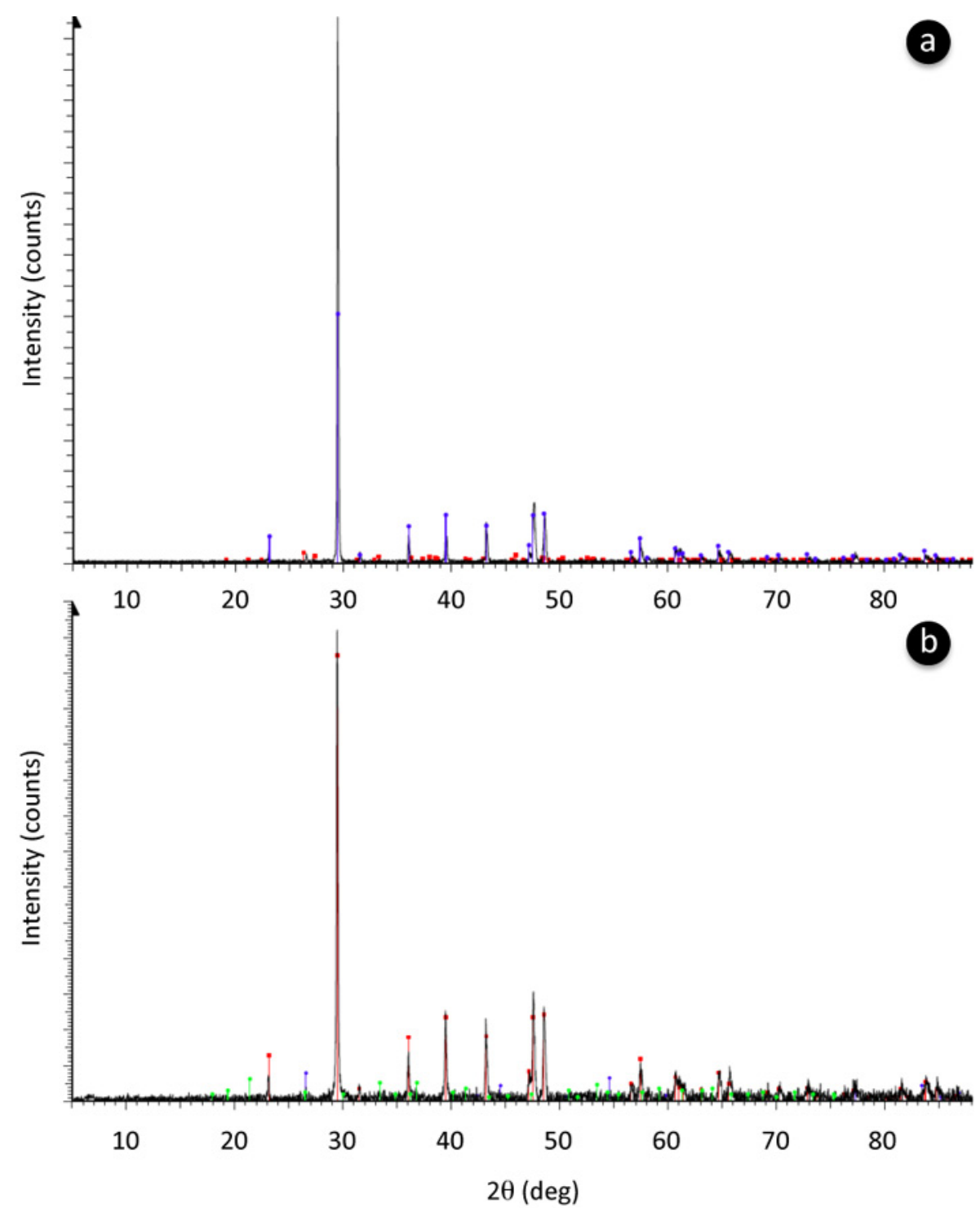

Fig. 7. XRD analyses of various zones of stalactite show that (a) the thick and thin layers consist mainly of calcite, and that (b) dark-brown crusts are amorphous as calcite is the only mineral present in the diffractogramm.

intermixed with EPS (Fig. 12c). The contact between calcite crystal and these crusts shows corrosion features (Fig. 12d). Where this cover is thin, microborings are still visible under randomly distributed nanofilaments (Fig. 12e, f). At the interface between calcite and oxy-hydroxides, partial dissolution of calcite rhomboedra is observed (Fig. 13). These rhombs are characterized by irregular outlines (Fig. 13b-d) and show a close relationship with microorganisms. Filaments are located on top of calcite crystals and part of iron oxides, suggesting that they developed contemporaneously (Fig. 13c, d).

Unlike spherical microborings, other cavities consist of tunnels that are locally covered by an alveolar lowmagnesium calcite network (Fig. 14). This network is magnesium-enriched compared to the calcite that forms the stalactite. Rare nanoparticles of manganese oxides are present, showing a crenulated surface structure (Fig. 14d).

\subsection{Laboratory iron-oxide precipitation experiments}

We designed a laboratory experiment to compare abiotic and biotic iron-oxide precipitation under controlled conditions, and to allow the characterization of newly formed precipitates. After being inoculated with the iron-rich medium, the biofilms are found encrusted with dark-brown mineral precipitates when viewed using phase-contrast light microscopy. Examination using SEM reveals rosettes with minor amounts of flakey globular aggregates and with a crenulated surface in the biofilm that formed from the dripwater (Fig. 15a). EDS analyses of these precipitates show that they contain Fe, C, 

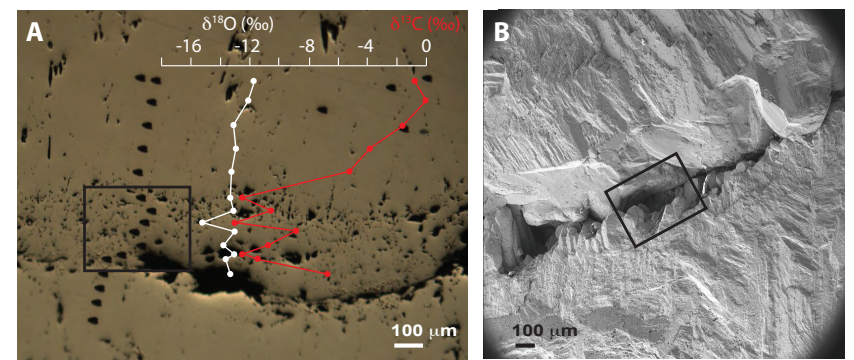

Fig. 8. Microphotographs of segments of stalactite sample after ionprobing. $\delta^{13} \mathrm{C}$ measurements indicate more negative values in the cavities, as shown by the SEM picture.

and $\mathrm{O}$, thus identifying them as iron oxides. XRD analysis of these precipitates verified them to be amorphous. While iron-oxide crystal aggregates are present in the abiotic cave water control, no rosettes have been observed (Fig. 15b).

\section{Discussion}

\subsection{Role of microbes in carbonate precipitation and weathering}

Potentially, microbes can influence the growth of speleothems by microbe mineralization, by trapping and binding detrital grains on the substrate, and/or by mediating mineral precipitation (Léveillé et al., 2000a, b; Cañaveras et al., 2001; Jones, 2001, 2010). In our sample, the thickly laminated columnar calcite crystals are enriched in ${ }^{13} \mathrm{C}$ (with $\delta^{13} \mathrm{C}$ values of $\sim 0 \%$ ) compared to small calcite crystals (ca. -6 to $-13 \%$ using SIMS), whereas no significant variations are observed in the SIMS $\delta^{18} \mathrm{O}$ values (Fig. 8). Several $\delta^{13} \mathrm{C}$ and $\delta^{18} \mathrm{O}$ SIMS profiles along with SEM including porous cracks confirm that the ${ }^{13} \mathrm{C}$ depletion is typically associated with the porous cracks, which are characterized by small low-magnesium calcite rhombs and local microbial filaments. More negative $\delta^{13} \mathrm{C}$ isotope signatures can result from microbial fractionation of C (Melim et al., 2001; Cacchio et al., 2004; Léveillé et al., 2007). The preferential uptake of ${ }^{12} \mathrm{C}$-enriched compounds during microbial mineralization leads to ${ }^{13} \mathrm{C}$-depletion in the precipitated carbonate compared to the source material (e.g., Lee et al., 1987; Pacton et al., 2012). More specifically, the observed carbon isotope depletion coincides with the location of the mineralized biofilm that served as the template for calcite precipitation. These unusual mineral morphologies, coupled with a high $\mathrm{Mg}^{2+}$ content (Fig. 4) are evidence for EPS-influenced organomineralization (Dupraz et al., 2004). Similar small magnesium calcite crystals have been recently observed in speleothem associated with microbial activity, suggesting a possible biomineralization process (Frisia et al., 2012). Analogous to freshwater microbial carbonates, precipitation appears to be initiated from EPS as

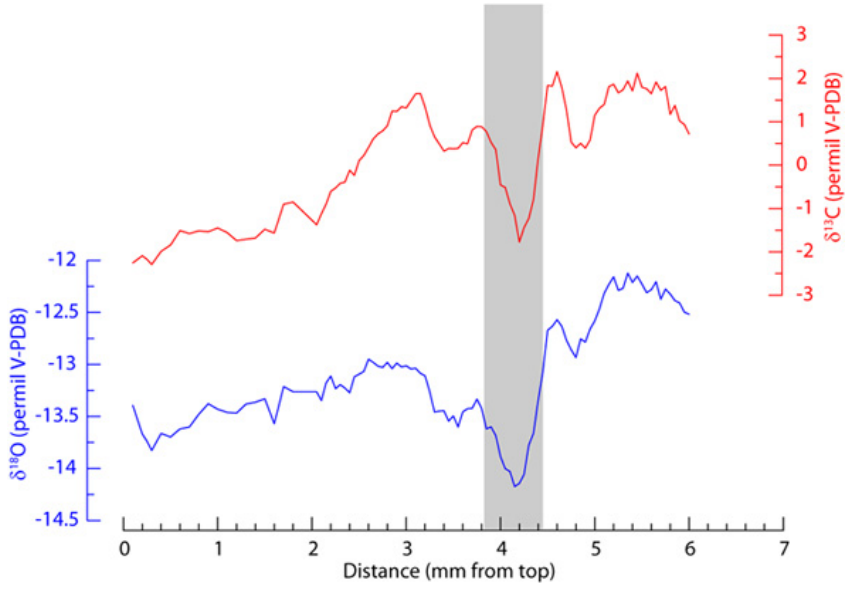

Fig. 9. Profile of $\delta^{13} \mathrm{C}$ and $\delta^{18} \mathrm{O}$ variations with depth in stalactite 2-N obtained by micro-drilling and conventional acid dissolution analysis. The grey area corresponds to a crack.

permineralized ${ }_{\mathrm{am}} \mathrm{Mg}$-Si phases (Sanz-Montero et al., 2008; Pacton et al., 2012). Many of the biofilms found throughout the stalactite commonly cover the surfaces of block-like calcite crystals. Therefore, biofilms seem to help initiate layer formation on the stalactite via organomineralization processes characterized by small calcite crystals. Subsequently, abiotic calcite precipitation leads to the formation of thicker columnar calcite crystals. The latter may be further colonized by endolithic microborers, as suggested by the coccoid shapes in the studied sample. These could be similar to endolithic microborings produced by algae and some cyanobacteria (Harris et al., 1979). Despite the fact that only a few taxa are found in the twilight zone of the cave, these microborers may be Geitleria calcarea, Loriella osteophila or other bacteria (Jones, 2010). While there is no evidence of trapping and binding or filament encrustation, this study gives further evidence of microbes indirectly influencing precipitation in a Pleistocene stalactite.

\subsection{Role of microbes in ferromanganese mineral formation}

The amorphous nature of ferromanganese oxides (documented by XRD) is the initial form of metal precipitated in caves and has been proposed as a typical feature of microbial precipitates (Northup and Lavoie, 2001; Spilde et al., 2005; Tebo et al., 1997). The globular and rosette arrangement of these oxides is however unexpected, unlike the wide range of morphologies described in the literature, e.g., bacterial filamentous and coccoid bodies, or sheet-like minerals (e.g., Chafetz et al., 1998).

Several researchers invoked metabolic precipitation mechanisms such as chemolithotrophy to trigger iron and/or manganese oxide formation (Peck, 1986; Northup, 2003; Northup et al., 2000; Spilde et al., 2005). Fortin and 

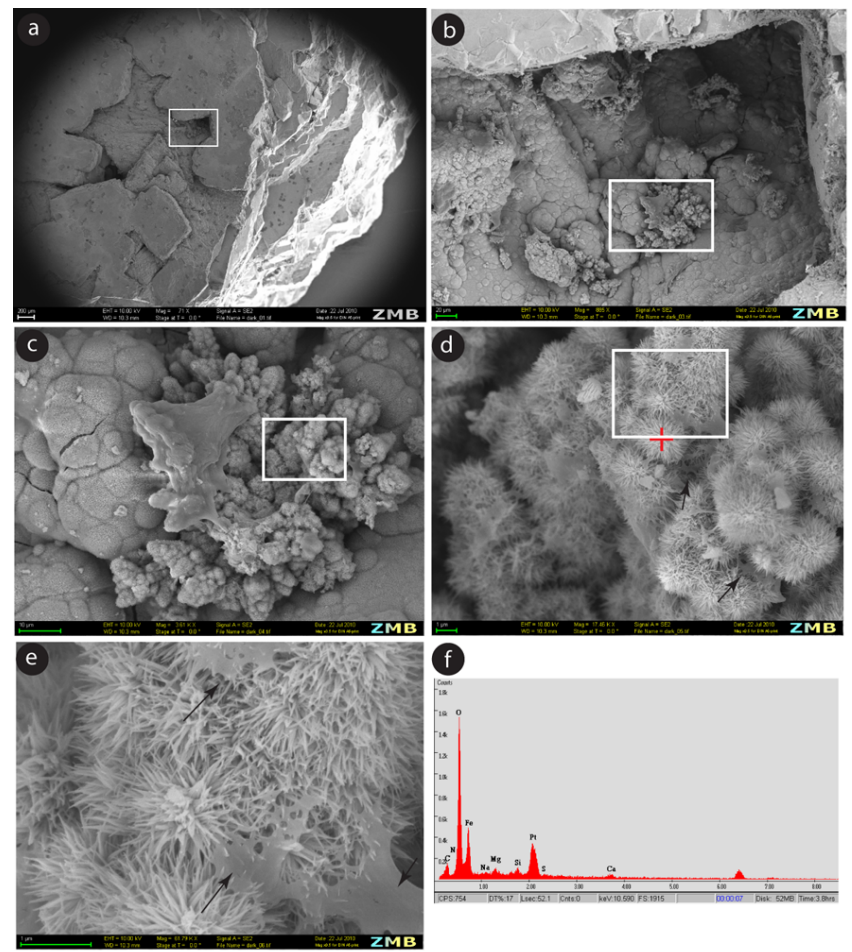

Fig. 10. Secondary electron images of the dark-brown crusts: (a) iron oxides are located in the depressions within calcite crystals; $(\mathbf{b}, \mathbf{c})$ globular structures with a size ranging from a few microns to 20 |mum; (d, e) spherical bodies are composed of acicular needles that have a radial arrangement. They display a close association with EPS (arrows), as the needles are within or below EPS; (f) elemental analysis showing that $\mathrm{Fe}$ and $\mathrm{O}$ are the main components of these crusts and are associated with a small contribution of $\mathrm{Mg}$ and $\mathrm{Si}$.

Ferris (1998) discuss the capability of bacteria to provide nucleation sites favorable for iron and manganese deposition.

Our laboratory experiments confirm the microbial origin of the Fe and Mn deposits in the Siberian stalactite. Although mineral precipitation occurred as mineral crusts within both abiotic and biotic systems, rosettes similar to those present in the stalactite sample SB-p6915 only form in the biotic system. Apparently, biofilms allow iron oxide formation with a different morphology than the abiotic system. These findings demonstrate that EPS promote rosette iron oxide formation without the requirement of any microbial metabolism, i.e., a passive mineralization of EPS. This suggests an EPSinfluenced organomineralization process (as opposed to induced, in which a microbial metabolism can change, e.g., the alkalinity) (e.g., Dupraz et al., 2009). This process may have been rather fast, as microbially accelerated Fe precipitation rates are more likely related to exopolysaccharides and microbial surface properties than to metabolic precipitation mechanisms (Kasama and Murakami, 2001).

The microbial community plays an active role in both the breakdown of bedrock and speleothem formation. Fer-
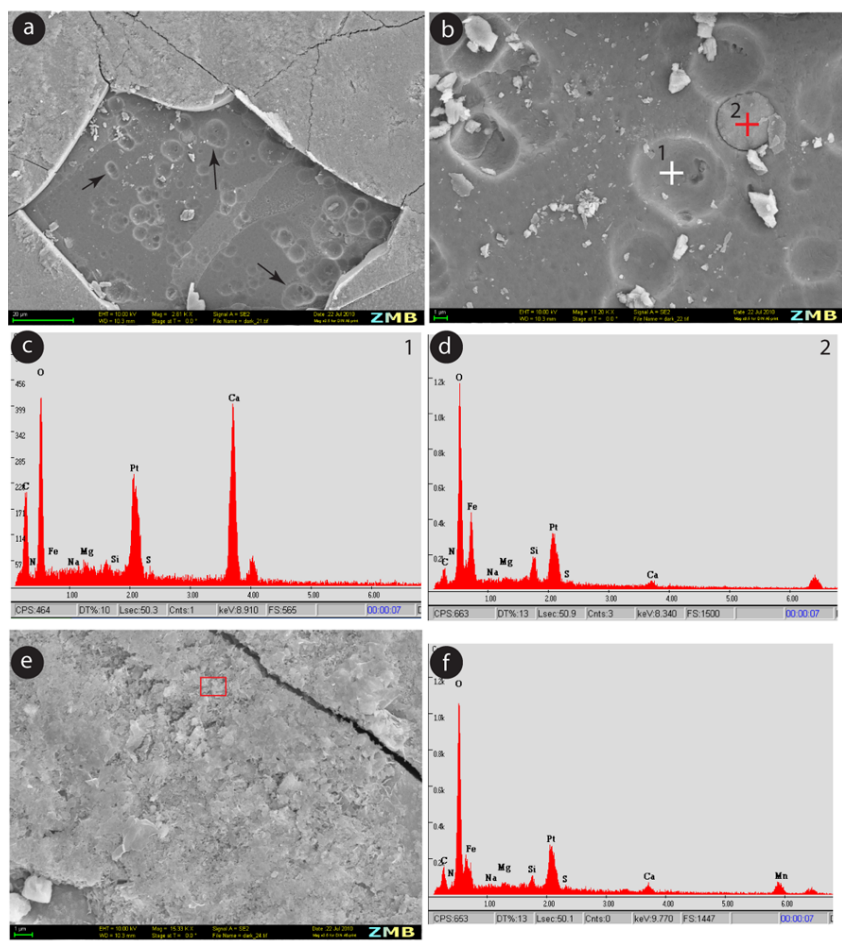

Fig. 11. Secondary electron images of the surface of the stalactite: (a) a thin layer cover calcite surface that includes microborings (arrows). They consist of solitary cells that are spherical in shape and average 1 to $10 \mu \mathrm{m}$ in diameter; (b) microborings include open borings (1) and resin casts (2); (c, d) elemental analyses indicate that open borings are made of low-magnesium calcite, whereas resin casts are made of $\mathrm{Fe}, \mathrm{O}$ and $\mathrm{Si}$; (e) the thin layer-covering calcite crystals are composed of nanofilaments forming flakes; (f) elemental analyses of this layer reveal that it is made of $\mathrm{Fe}, \mathrm{Si}$ and $\mathrm{Mn}$.

romanganese deposits in caves are usually considered an end-product of microbially assisted dissolution and leaching of the underlying host carbonate, and of the enrichment of iron and manganese through microbial oxidation (Northrup et al., 2000, 2003; Boston et al., 2001). Ferric iron is essentially insoluble at neutral $\mathrm{pH}$, and amorphous $\mathrm{Fe}$ (III) oxide is the predominant form of $\mathrm{Fe}$ (III) reduced in these environments (Murray, 1979; Schwertmann and Taylor, 1977). $\mathrm{Fe}(\mathrm{II})$ and $\mathrm{Mn}(\mathrm{II})$ may have been released into the cave environment by iron- and manganese-oxidizing bacteria (Northup et al., 2000).

Biotic oxidation of metals can occur either indirectly or directly. Indirect oxidation results from the release of oxidants, acids, or bases into the environment surrounding the microbial cell, and leads to a change in redox conditions in the surrounding microenvironment (for a review see Tebo et al., 1997). Direct oxidation may occur through the binding of ion metal to negatively charged substances on the bacterial cell surface, or through the action of metal-binding proteins that are both intra- and extracellular (Ghiorse, 1984). 

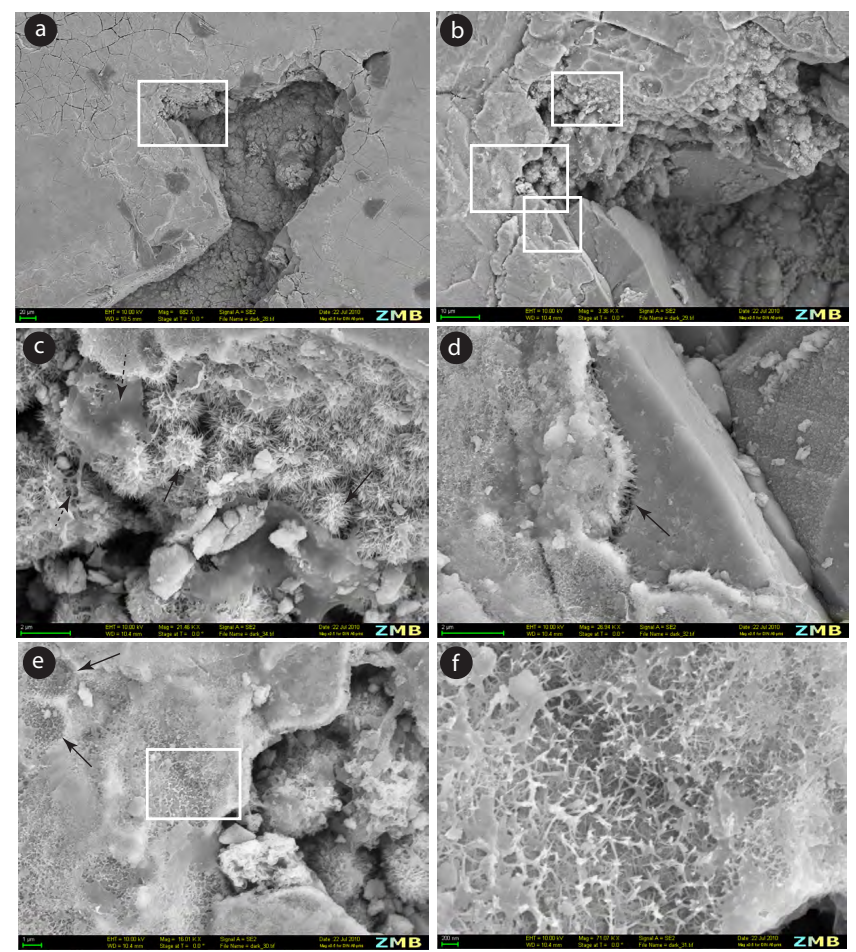

Fig. 12. Secondary electron images of the corrosion features: (a, b) calcite crystals corroded by iron oxides close to depressions, as shown by irregular outlines; (c) iron oxides characterized by fibrous radial structures (arrows), which are intermixed with EPS (dashed arrows); (d) the contact between calcite crystal and these crusts shows corrosion features (arrow); (e) where this cover is thin, microborings are still visible (arrows); (f) iron oxides are composed of randomly arranged nanofilaments.

The observed layers, rich in ferromanganese oxides, suggest periods of intensified weathering and/or erosion above the cave caused by humid (and relatively warmer, because of permafrost absence) conditions. Deposition of stalactite carbonate (and the crusts) was only possible during warm intervals when permafrost was absent above the cave. Contrary to manganese stromatolites found in caves (Rossi et al., 2010), the deposits found in our study were essentially formed at the speleothem-air interface (e.g., Spilde et al., 2005).

\section{$5.3 \quad \delta^{13} \mathrm{C}$ and $\delta^{18} \mathrm{O}$ as paleoclimate proxies}

Since $\delta^{13} \mathrm{C}$ and $\delta^{18} \mathrm{O}$ ratios are routinely used as paleoclimate proxies, we investigate if microbial activity might have a significant influence on the isotopic composition of the carbonate, thus complicating the interpretation of isotope time series in terms of climatic variations.

Carbon in speleothem calcite has three main sources: (1) $\mathrm{CO}_{2}$ produced in the soil by respiration of organic material, with $\delta^{13} \mathrm{C}$ values ranging from -15 to $-25 \%$; (2) $\mathrm{C}$ from atmospheric $\mathrm{CO}_{2}$, normally with $\delta^{13} \mathrm{C}$ values close to $-7 \%$; and (3) inorganic carbon from dissolved carbonate host rock,
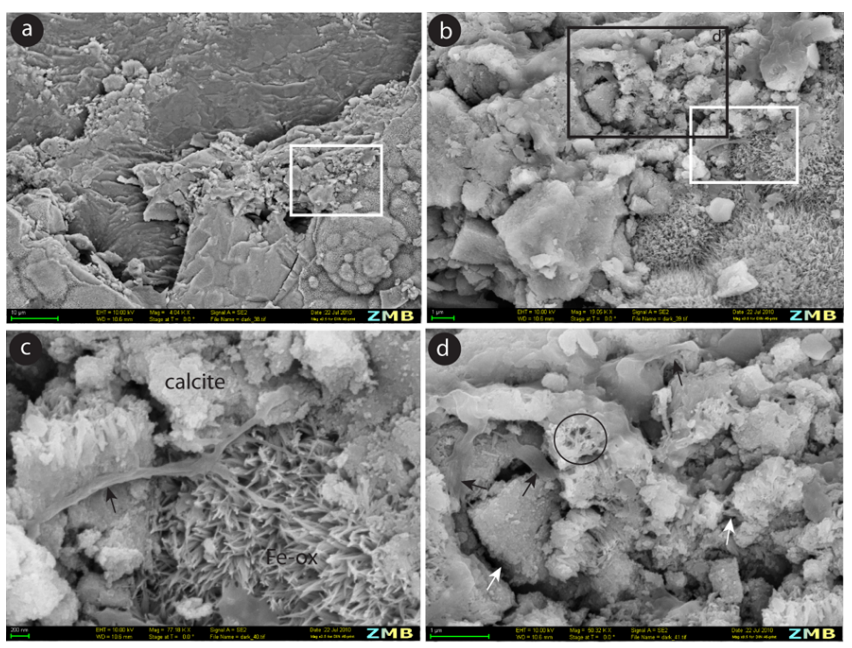

Fig. 13. Secondary electron images of the relationships between dark-brown crusts and calcite crystals: $(\mathbf{a}, \mathbf{b})$ partial dissolution of calcite rhomboedra as shown by the porous texture (black square); $(\mathbf{c}, \mathbf{d})$ irregular outlines of calcite rhombs (white arrows) closely associated with microorganisms (black arrows).

which typically has a $\delta^{13} \mathrm{C}$ value near zero (e.g., Johnson et al., 2006; Cruz et al., 2006; Cacchio et al., 2004). Longterm changes in speleothem $\delta^{13} \mathrm{C}$ values can reflect various changes in the carbon budget, such as shifts in the type of vegetation overlying the cave (Denniston et al., 1999), degassing changes associated with high or low drip rates (Mühlinghaus et al., 2007), or variations in host rock dissolution. Lower drip rates and prolonged $\mathrm{CO}_{2}$ degassing as well as a change from taiga forest to open tundra during times of massive drying would all result in enriched $\delta^{13} \mathrm{C}$ values. Major alterations of vadose fluid pathways or changes in dripwater $\delta^{13} \mathrm{C}$ composition are also unlikely, and thus we argue that more negative $\delta^{13} \mathrm{C}$ values are most likely the result of microbially mediated processes. The strong carbon isotope depletion within the crack (Fig. 9) found by SIMS analysis, along with EPS-like morphological evidence, further support a microbial origin.

However, would microbial activity have a significant influence on conventional (bulk) IRMS isotope analysis? The observed SIMS $\delta^{13} \mathrm{C}$ decrease is less clearly reflected in the IRMS stable isotope profile. The microbial mineralization in only very thin layers on the sample likely results in an attenuated IRMS $\delta^{13} \mathrm{C}$ decrease observed in bulk carbonate analysis ( $-2 \%$ o compared to -6 to $-13 \%$ in the SIMS samples). The IRMS $\delta{ }^{13} \mathrm{C}$ variability found throughout the analyzed section (unrelated to the crack) also suggests that the microbial signature is of negligible importance for the overall isotope profile. We are positive that the studied IRMS $\delta^{13} \mathrm{C}$ tracks record mainly environmental changes, and that the microbial overprint is very small, owing to the scale differences when comparing the ultra-high resolution SIMS and bulk IRMS carbonate analyses. 


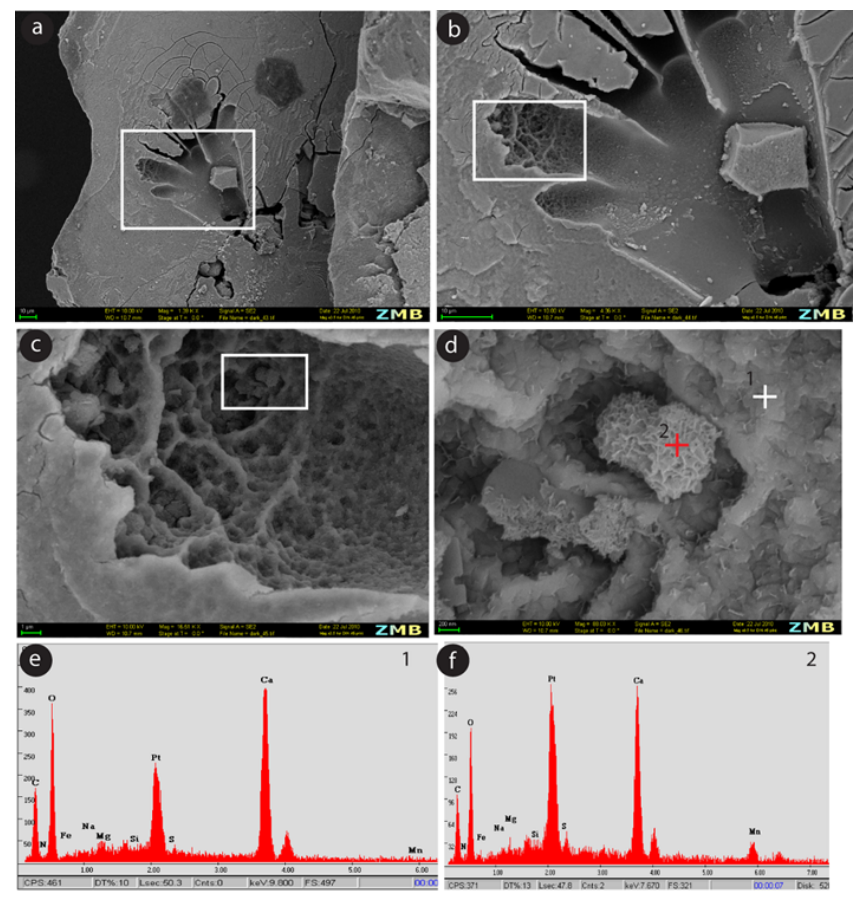

Fig. 14. Secondary electron images of the ferromanganese crusts covering microborings in calcite: (a) microborings made of tunnels; (b, c) part of tunnels covered by an alveolar network; (d) particule displaying a crenulated surface structure; (e) elemental analysis of the alveolar network mainly composed of low-magnesium calcite; (f) elemental analysis of the manganese oxide particle.

The $\delta^{18} \mathrm{O}$ profiles found by both methods, SIMS and IRMS, can be explained by abiotic processes. The IRMS oxygen isotope profile shows a prominent shift from -12.5 to $<-14 \%$ near the crack, a feature also found in the SIMS profile. This finding is congruent with the notion of hiatuses being caused by permafrost build-up. $\delta^{18} \mathrm{O}$ in Siberian meteoric water shows a strong relationship with temperature (Brezgunov et al., 1998), and cooling associated with permafrost development would likely lead to very negative $\delta^{18} \mathrm{O}$ values just before a hiatus. Permafrost thaw with the onset of warmer periods again allows water infiltration, probably with isotopically depleted water entering the cave initially.

Thus, while $\delta^{13} \mathrm{C}$ is likely affected by microbial activity under beneficial circumstances, this influence is of too small a scale to be recovered by conventional IRMS analysis. $\delta^{18} \mathrm{O}$ is more likely governed by abiotic processes such as temperature and the $\delta^{18} \mathrm{O}$ signature of the meteoric water, and no microbial influence can be attested in this case.

Speleothem calcite formation through purely abiogenic processes has already been challenged (Jones, 2009, 2010, 2011), and it seems that repeated microbial-calcite association is found in a wide variety of climatic settings in caves (e.g., Frisia et al., 2012; Jones, 2011). Further investigations combining microscopy and isotope geochemistry (SIMS) are required in caves from different climatic zones to constrain

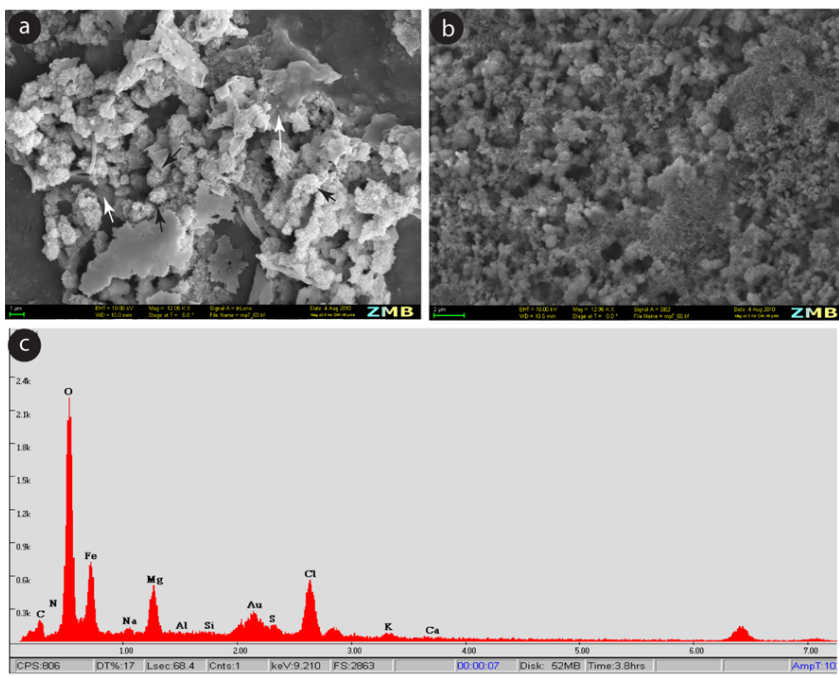

Fig. 15. Secondary electron images of the ferromanganese crusts: (a) the biofilm inoculated in the iron-rich medium. Note that $1 \mu \mathrm{m}$ wide rosettes showing a crenulated surface (black arrows) are closely related to extracellular polymeric substances (white arrows). (b) Detail of amorphous iron oxides in the sterile iron-rich medium appearing as nanoglobules. (c) Elemental analyses of the rosettes (a) indicating a strong contribution of magnesium in the iron oxides.

the role of microbes in speleothem formation related to hiatuses and/or carbonate disruptions.

\subsection{The host rock as potential source of iron and manganese}

One source of iron or manganese could be the host rock, independent of microbially mediated processes. While according to Kadlec et al. (2008) and Filippov (2000), no iron-bearing minerals are present in the host rock above the cave, it seems that early geological studies in the vicinity of the cave found sparse sulfide-rich deposits above the cave (Odintsev et al., 1947; Egorov, 2011). The reason why no iron oxides have been recorded since then remains unknown. Oxidation of pyrite in the host rock could be a potential source of iron by reaction with either oxygen or ferric iron (usually occurring in acidic environments) by acidophilic microbes, or under anoxic conditions at a circumneutral $\mathrm{pH}$ through the "thiosulfate pathway" (Luther and George, 1987; Moses et al., 1987; Schippers and Jorgensen, 2001). Ferric ions produced by the oxidation of solid or aqueous phase $\mathrm{Fe}$ (II) with oxygen can then be precipitated and immobilized as a hydroxide, an oxide, a phosphate or a sulfate, or, if bound to soluble organic ligands, converted to soluble complexes and dispersed from their source. However, no acidic conditions (leading to carbonate dissolution) or anoxic deposits (leading to OM accumulation) that could support this interpretation have been found on top of the cave. Botovskaya Cave was within the vadose zone during stalactite deposition 
(stalactite formation can only happen in air-filled voids), preventing anoxic or acidic conditions in carbonate rock above the cave. Another reason to reject this source is that iron deposits/coatings have only been observed in the oldest part of the stalactite, and have not been found in other young (i.e., Holocene, MIS-5.5, MIS-7, MIS-9 and MIS-11) nearby speleothems from this cave. If the host rock were a source of iron, we would expect transport of iron into the cave during all speleothem growth periods (warm interglacials without continuous permafrost).

Although we cannot strictly rule out the sulfide-rich deposit hypothesis at this time, the most likely hypothesis to permit $\mathrm{Fe}$ and $\mathrm{Mn}$ mobilization remains the presence of a local peat bog above the cave at the time of deposition and the seeping of acidic/anoxic water from there into the rock fissures above the cave.

\subsection{Palaeoenvironmental appraisal of the deposited crusts}

Siberian peats are especially rich in Fe and Mn (Efremova et al., 2001) and were widely distributed in this area during the Pleistocene and Holocene (e.g., Krivonogov et al., 2004). At present, small peat bogs are common on the high flat plateau near the cave. Although no peat bog is found above this part of the cave today, it is possible that one existed there earlier, causing the peat bog water, rich in $\mathrm{Fe}, \mathrm{Mn}$ and organic materials, to infiltrate the cave, and was the most likely source for the $\mathrm{Mn}$ (II) and $\mathrm{Fe}(\mathrm{II})$ deposited as dark crusts.

Most of the iron present in the modern soil is of the paramagnetic $\mathrm{Fe}^{3+}$ form, which may be the result of weathering of paramagnetic minerals during pedogenetic processes (Evans and Heller, 2004; Kadlec et al., 2008). Enhanced erosion might have occurred during the Middle or Late Pleistocene above the cave (Kadlec et al., 2008), but detailed chronological constrains are lacking. Precipitation of iron and manganese oxides in caves depends on the $\mathrm{pH}$ of the medium and is closely tied to the distance from the substrate rock (Gazquez et al., 2011). At around $\mathrm{pH}$ 6, precipitation of iron oxides is frequent, whilst close to $\mathrm{pH} 8.5$, manganese oxides can be precipitated (Onac, 1996). However, biological iron oxidation can also occur at circumneutral $\mathrm{pH}$ (Emerson and Moyer, 1997). This is in agreement with the fact that iron oxides are found contemporaneous with EPS. Moreover, the calcitic microboring casts observed under the ferrous cover would have been dissolved at a lower $\mathrm{pH}$.

In the stalactite, the Mn-Fe mineralization is concentrated on the side where the layers' thickness is reduced, indicating that $\mathrm{Mn}-\mathrm{Fe}$ deposits precipitated in places where the water flow was minimal. Higher water flow took place on the other side of the stalactite, leading mainly to calcite deposition. It is possible that microbial colonies preferred to occupy the area with minimal water flow, as it is known that increasing hydrodynamic conditions reduce biofilm adhesion (Lau and Liu, 1993). Surface erosion eventually led to the draining of the hypothetical peat bog into the Boty River valley, followed by oxidation of the peat deposits, associated mobilization of $\mathrm{Fe}$ and $\mathrm{Mn}$, and formation of Mn-Fe deposits there. Disappearance of the peat bog sediment would have stopped the infiltration of $\mathrm{Mn}$ and $\mathrm{Fe}$, and thus the recording of $\mathrm{Mn}-\mathrm{Fe}$ deposits in the stalactite.

\subsection{Potential implications of microbes for speleothem genesis}

The hypothesis that the growth of stalactites and stalagmites can be mediated by microbes has already been postulated by many studies (e.g., Cox et al., 1989a, b; Cunningham et al., 1995; Cañaveras et al., 2001; Jones, 2001, 2010; Melim et al., 2001, 2008, 2009; Basker et al., 2005, 2007, 2009; Frisia et al., 2012). However, recognizing and identifying the biosignatures of microbial processes is inherently difficult, especially in fossil systems such as speleothems that lack preserved microbes and/or EPS (Barton et al., 2001; Barton and Northup, 2007; Engel, 2007; Melim et al., 2009; Jones et al., 2011). To our knowledge this is the first study that constrains $\delta^{13} \mathrm{C}_{\text {carb }}$ depletion along with detailed microscopical investigations, thereby restricting a discussion of broader (geographical) implications. Nevertheless, such records might occur in other climatic settings, thus opening up the possibility of investigating the role of microbes as contributors to speleothem formation under temperate and tropical conditions (e.g., Frisia et al., 2012; Jones et al., 2011), and possibly as recorders of climatic changes. Although microbial carbonate formation can be mediated under different climatic conditions, including cold and dry climates especially related to permafrost occurrence, e.g., Pellerin et al. (2009), the timing of periods of calcite growth initiation and cessation cannot be fixed with certainty at this stage. For example, carbonate lamination in stromatolites is interpreted as recording the periodic response of a microbial community to daily, seasonal, or yearly environmental forcing, and also to regional climate forcing (Petryshin et al., 2012), but the timing of carbonate laminae formation can vary considerably depending on geological settings (e.g., Chivas et al., 1990; Paull et al., 1992; Font et al., 2010; Petryshin et al., 2012). It has been suggested that microbial processes similar to stromatolite-like layers in speleothems mark periods of reduced drip rate, and thus might potentially be indicative of dry phases (Frisia et al., 2012). Similarly, in this study, hiatuses caused by permafrost build-up are closely related to porous cracks (small low-magnesium calcite rhombs and local microbial filaments) and associated with ${ }^{13} \mathrm{C}$ depletion. Therefore, these microbial biosignatures might be an indicator of environmental change (freezing or dry conditions) in different climatic settings. Similar investigations combining microscopy and in situ isotope geochemistry (SIMS) are definitely required in caves from different climatic zones in order to better constrain the role of microbes in speleothem formation related to hiatuses and/or carbonate disruptions. 


\section{Conclusions}

The mere presence of microbes in a speleothem does not inform us if they played a formative role in the growth and development of that speleothem. Stalactite formation Botovskaya Cave (Siberia) is the result of a combination of both biotic and abiotic processes. It is composed of an alternation of columnar prismatic calcite and anhedral calcite locally associated with ferromanganese oxides. Anhedral calcite crystals are closely tied with permineralized EPS as amorphous $\mathrm{Mg}$-Si phases that constitute the base of each layer. The origin of ferromanganese deposits is related to the mobilization of polymetallic minerals in peats above the cave. Metal ions (including $\mathrm{Fe}^{2+}$ and $\mathrm{Mn}^{2+}$ ) released into the cave under reducing conditions are oxidized and fixed by microbes and evolve further to oxides and hydroxides of low crystallinity through EPS. Both carbonate and ferromanganese oxides are triggered by passive mineralization of EPS (i.e., EPS-influenced organomineralization processes), suggesting that no metabolisms are required for mineral formation in caves. Therefore, microbial involvement in the stalactite's formation is supported by multiple evidence, including:

- internal fabrics similar to EPS morphology,

- microbial permineralization as am Mg-Si phases, and

- consistent depletion of $\delta^{13} \mathrm{C}$ values for porous (putative biogenic) versus columnar (putative abiogenic) layers.

Microbially induced $\delta^{13} \mathrm{C}$ fractionation leads to negative isotope signatures, which are (in our case) of too small a scale to be reflected in conventional isotope analysis. Along with abiotic calcite, microbial calcite formation in speleothem has been recorded in caves from different climatic settings, and might suggest that biomineralization processes have to be considered in speleothem formation.

A general scheme for the precipitation sequence of the Botovskaya stalactite could be reconstructed as follows: (1) deposition of laminae (formed by organomineralization followed by abiotic precipitation); (2) corrosion/etching through microboring cyanobacteria-like organisms; (3) development of a peat bog above the cave, recorded in the stalactite through iron- and manganese-layer deposition initiated by iron- and manganese-oxidizing bacteria; (4) metal ions trapped by in situ biofilms at circumneutral $\mathrm{pH}$ and precipitation of ferromanganese oxides as rosettes within EPS; (5) destruction of the peat bog and subsequent abiotic calcite deposition. All these developments took place well before ca. $500 \mathrm{ka} \mathrm{BP}$, as evidenced by the age of the outer layer of the studied sample.

The U-series date and the observed hiatuses indicate a Pleistocene date for this unusual stalactite sample. A more detailed chronology can only be established by U-Pb dating. Hypothetically this could push the deposition of the dark crusts into even older periods, from Middle Pleistocene to Pliocene.

\section{Supplementary material related to this article is available online at http://www.biogeosciences.net/10/ 6115/2013/bg-10-6115-2013-supplement.zip.}

Acknowledgements. We thank ETH Zurich, Pethros (Petrobras) and the Swiss National Science Foundation (grants No. 200020_127327 and CRSI22_132646/1) for financial support, and the University of Zurich for access to electron micrograph scanning facilities. We thank G. M. Henderson from the University of Oxford for laboratory and funding support. Birgit Plessen (GFZ Potsdam) kindly supported stable isotope analyses of stalagmites BOTI-881 and BOTI-4537. We also thank Saskia Bindschedler, Sophie Verheyden and Amy Frappier for helpful constructive comments that greatly improved the manuscript.

Edited by: D. Gillikin

\section{References}

Baldini, J., McDermott, F., Hoffmann, D., Richards, D., and Clipson, N.: Very high-frequency and seasonal cave atmosphere $\mathrm{PCO}_{2}$ variability: implications for stalagmite growth and oxygen isotope-based paleoclimate records, Earth Planet. Sci. Lett., 272, 118-129, 2008.

Bar-Matthews, M., Ayalon, A., and Kaufman, A.: Late Quaternary paleoclimate in the eastern Mediterranean region from stable isotope analysis of speleothems at Soreq Cave, Israel, Quatern. Res., 47, 155-168, 1997.

Barton, H. A. and Northup, D. E.: Geomicobiology in cave environments: past, current and future perspectives, Journal of Cave and Karst Studies, 69, 163-178, 2007.

Barton, H. A., Spear, J. R., and Pace, N. R.: Microbial life in the underworld: biogenicity in secondary mineral formations, Geomicrobiol. J., 18, 359-368, 2001.

Baskar, S., Baskar, R., Mauclaire, L., and McKenzie, J. A.: Role of microbial community in stalctite formation, Sahastradhara caves, Dehradun, India, Current Science, 88, 1305-1308, 2005.

Baskar, S., Baskar, R., Mauclaire, L., and McKenzie, J. A.: Microbially induced calcite precipitation by culture experiments possible origin for stalactites in Sahastradhara, Dehradun, India, Current Science, 90, 58-64, 2006.

Baskar, S., Baskar, R., and Kaushik, A.: Evidences for microbial involvement in the genesis of speleothem carbonates, Borra Caves, Visakhapatnam, India, Current Science, 92, 350-355, 2007.

Baskar, S., Baskar, R., Lee, N., and Theophilus, P. K.: Speleothems from Mawsmai and Krem Phyllut caves, Meghalaya, India: some evidences on biogenic activities, Environ. Geol., 57, 1169-1186, 2009.

Boston, P. J., Spilde, M. N., Northup, D. E., Melim, L. A., Soroka D. S., Kleina, L. G., Lavoie, K. H., Hose, L. D., Mallory, L. A. Dahm, C. N., Crossey, L. J., and Schelble, R. T.: Cave biosignatures suites: Microbes, minerals, and Mars, Astrobiol. J., 1, 25-55, 2001 
Bourges, F., Genthon, P., Mangini, A., and D'Hulst, D.: Microclimates of L'Aven D'Orgnac and other French limestone caves (Chauvet, Esparros, Marsoulas), Int. J. Climatol., 26, 1651-1670, 2006.

Breitenbach, S.: High-resolution isotope measurements $\left(\delta^{18} \mathrm{O}\right.$ and $\delta^{13} \mathrm{C}$ ) from Siberian stalagmites as potential palaeoclimatic proxies [MSc. thesis], Humboldt Universität zu Berlin, 72 pp., 2004.

Breitenbach, S. F. M. and Bernasconi, S. M.: Carbon and oxygen isotope analysis of small carbonate samples (20 to $100 \mu \mathrm{g})$ with a GasBench II preparation device, Rapid Commun. Mass Spectrom., 25, 1910-1914, 2011.

Brezgunov, B. S., Yesikov, A. D., Ferronsky, V. I., and Sal'nova, L. V.: Spatial-time variations of stable oxygen isotope composition in precipitation and river waters of northern Eurasia and their relationship to temperature changes, Vodnye Resourcy, 25, 99104, 1998 [in Russian].

Brook, G. A., Burney, D. A., and Cowart, B. J.: Desert paleoenvironmental data from cave speleothems with examples from the Chihuahuan, Somali-Chalbi, and Kalhari deserts, Paleogeogr. Paleoclimatol. Paleoecol., 76, 311-329, 1990.

Broughton, P. L.: Environmental implications of competitive growth fabrics in stalactitic carbonate, Internat. J. Speleol., 13, 31-41, $1983 \mathrm{a}$.

Broughton, P. L.: Lattice deformation and curvature in stalactitic carbonate, Internat. J. Speleol., 13, 19-30, 1983b.

Broughton, P. L.: Secondary origin of the radial fabric in stalactitic carbonate, Internat. J. Speleol., 13, 43-66, 1983c.

Cacchio, P., Contento, R., Ercole, C., Cappucio, G., Martinez, M. P., and Lepidi, A.: Involvement of microorganisms in the formation of carbonate speleothems in the Cervo Cave (l'Aquila-Italy), Geomicrobiol. J., 21, 497-509, 2004.

Caldwell, D. E. and Caldwell, S. J.: Fine structure of in situ microbial deposits, Geomicrobiol. J., 2, 39-53, 1980.

Cañaveras, J. C., Sanchez-Moral, S., Soler, V., and Saiz-Jimenez, C.: Microorganisms and microbially induced fabrics in cave walls, Geomicrobiol. J., 18, 223-240, 2001.

Chafetz, H. S., Akdim, B., Julia, R., and Reid, A.: Mn- and Fe-rich black travertine shrubs: bacterially (and nanobacterially) induced precipitates, J. Sediment. Res., 68, 404-412, 1998.

Chivas, A. R., Torgersen, T., and Polach, H. A.: Growth rates and Holocene development of stromatolites from Shark Bay, Western Australia, Austral. J. Earth Sci., 37, 113-121, 1990.

Cox, G., James, J. M., Leggett, K. E. A., and Osborne, R. A. L.: Cyanobacterially deposited speleothems: subaerial stromatolites, Geomicrobiol. J., 7, 245-252, 1989a.

Cox, G., James, J. M., Leggett, K. E. A., and Osborne, R. A. L.:, Stromatolitic crayfish-like stalagmites, Bristol Speleological Society, Proceedings, 18, 339-358, 1989 b.

Cruz, Jr., F. W., Burns, S. J., Karmann, I., Sharp, W. D., Vuille, M., and Ferrari, J. A.: A stalagmite record of changes in atmospheric circulation and soil processes in the Brazilian subtropics during the Late Pleistocene, Quat. Sci. Rev., 25, 2749-2761, 2006.

Cunningham, K. I., Northup, D. E., Pollastro, R.M., Wright, W. G., and Larock, E. J.: Bacteria, fungi and biokarst in Lechuguilla Cave, Carlsbad Caverns National Park, New Mexico, Environ. Geol., 25, 2-8, 1995.

Decho, A. W.: Microbial exopolymer secretions in ocean environments: their role(s) in food webs and marine processes. In:
Barnes M (ed) Oceanography marine biology annual review, Aberdeen University Press, Aberdeen, 73-153, 1990.

Denniston, R. F., Gonzalez, L. A., Baker, R. G., Asmerom, Y., Reagan, M. K., Edwards, R. L., and Alexander, C. E.:. Speleothem evidence for a sharp and long-term prairie-forest ecotone at the northeast border of the middle Holocene prairie peninsula, The Holocene, 9, 671-676, 1999.

Denniston, R. F., DuPree, M., Dorale, J. A., Asmerom, Y., Polyak, V. J., and Carpenter, S. J.: Episodes of late Holocene aridity recorded by stalagmites from Devil's Icebox Cave, central Missouri, USA, Quatern. Res., 68, 45-52, 2007.

Díaz-Visurraga, J., Cárdenas, G., and García, A.: Morphological changes induced in bacteria as evaluated by electron microscopy, in: Microscopy: Science, Technology, Applications and Education, edited by: A. Méndez-Vilas and J. Díaz, 307-315, 2010.

Dorale, J. A., Gonzalez, L. A., Reagan, M. K., Pickett, D. A., Murrell, M. T. and Baker, R. G.: A high-resolution record of Holocene climate change in speleothem calcite from Cold Water Cave, northeast Iowa, Science, 258, 1626-1630, 1992.

Dupraz, C., Visscher, P. T., Baumgartner, L. K, and Reid, R. P.: Microbe-mineral interactions: early $\mathrm{CaCO}_{3}$ precipitation in a $\mathrm{Re}-$ cent hypersaline lake (Eleuthera Islands, Bahamas), Sedimentology, 51, 745-765, 2004.

Dupraz, C., Reid, R. P., Braissant, O., Decho, A. W., Norman, R. S., and Visscher, P. T.: Processes of Carbonate Precipitation in Modern Microbial Mats, Earth Sci. Rev., 6, 141-162, 2009.

Efremova, T. T., Efremov, S. P., Koutsenogii, K. P., and Peresedov, V. F.: Biogeochemical migration of metals of the iron group during the peat bog accumulation in the eutrophic marsh of Western Siberia, J. Radioanalyt. Nucl. Chem., 2417, 4109-424, 2001.

Egorov, K. N.: Mikhail M. Odintsov's contribution to development of the mineral and raw materials complex of the Eastern Siberia, Geodynam. Tectonophys. 2, 325-340, 2011.

Emerson, E. and Moyer, C. : Isolation and characterization of novel iron-oxidizing bacteria that grow at circumneutral pH, Appl. Environ. Microbiol., 63, 4784-4792, 1997.

Engel, A. S.: Observations on the biodiversity of sulfidic karst habitats, J. Cave Karst Studies, 69, 187-206, 2007.

Evans, M. E. and Heller, F.: Environmental Magnetism: Principles and Applications of Enviromagnetics, San Diego, Academic Press, p. 299, 2004.

Filippov, A. G.: Speleogenesis of the Botovskaya Cave, Eastern Siberia, Russia, in: Speleogenesis: Evolution of Karst Aquifers, edited by: Klimchouk, A., Ford, D., Palmer, A., and Dreybrodt, W., National Speleological Society, 282-286, 2000.

Font, E., Nédélec, A., Trindade, R. I. F., and Moreau, C.: Fast or slow melting of the Marinoan snowball Earth? The cap dolostone record, Palaeogeography, Palaeoclimatology, Palaeoecology, 295, 215-225, 2010.

Forti, P.: Biogenic spelethems: an overview, Internat. J. Speleol., 30, 39-56, 2001.

Fortin, D. and Ferris, F. G.: Precipitation of iron, silica, and sulfate on bacterial cell surfaces, Geomicrobiol. J., 15, 309-324, 1998.

Frisia, S., Fairchild, I. J., Fohlmeister, J., Miorandi, R., Spöotl, C., and Borsato, A.: Carbon massbalance modelling and carbon isotope exchange processes in dynamic caves, Geochim. Cosmochim. Ac., 75, 380-400, 2011.

Frisia, S., Borsato, A., Drysdale, R. N., Paul, B., Greig, A., and Cotte, M.: A re-evaluation of the palaeoclimatic significance 
of phosphorus variability in speleothems revealed by highresolution synchrotron micro XRF mapping, Clim. Past, 8, 20392051, doi:10.5194/cp-8-2039-2012, 2012.

Gasquez, F., Calafora, J. M., and Forti, P. : Black Mn-Fe crusts as palaeoenvironmental markers, Internat. J. Speleol., 40, 163-169, 2011.

Ghiorse, W. C.: Biology of iron-and manganese-depositing bacteria, Annu. Rev. Microbiol., 38, 515-550, 1984.

Harris, P. M., Halley, R. B., and Lukas, K. J.: Endolith microborings and their preservation in Holocene-Pleistocene (BahamaFlorida) ooids, Geology, 7, 216-220, 1979.

Hou, J. Z., Tan, M., Cheng, H., and Liu, T. S.: Stable isotope records of plant cover change and monsoon variation in the past 2200 years: evidence from laminated stalagmites in Beijing, China. Boreas 32, 304-313, 2003.

Johnson, K. R., Hu, C. Y., Belshaw, N. S., and Henderson, G. M.: Seasonal trace-element and stable-isotope variations in a Chinese speleothem: The potential for high-resolution paleomonsoon reconstruction, Earth Planet. Sci. Lett., 244, 394-407, 2006.

Jones, B.: Microbial activity in caves - a geological perspective, Geomicrobiol. J., 18, 1-13, 2001.

Jones, B. and Motyka, A.: Biogenic structures and micrite in stalactites from Grand Cayman Island, British West Indies, Canad. J. Earth Sci., 24, 1402-1411, 1987.

Jones, B.: Microbes in caves: agents of calcite corrosion and precipitation, in: Tufas and Speleothems: Unravelling the microbial and physical controls, edited by: Pedley, H. M. and Rogerson, M., Geological Society, London, Special Publications, 336, 730, 2010.

Jones, B.: Stalactite growth mediated by biofilms: example from Nani Cave, Cayman Brac, British West Indies, J. Sediment. Res., 81, 322-338, 2011.

Kadlec, J., Chadima, M., Lisa, L., Hercman, H., Osintsev, A., and Oberhänsli, H.: Clastic cave deposits in Botovskaya Cave (Eastern Siberia, Russian Federation), J. Cave Karst Studies, 70, 142 155,2008

Kasama, T. and Murakami, T.: The effect of microorganisms on Fe precipitation rates at neutral $\mathrm{pH}$, Chem. Geol., 180, 117-128, 2001.

Kendall, A. C. and Broughton, P. L.: Origin of fabrics in speleothems composed of columnar calcite crystals, J. Sediment. Petrol., 48, 519-538, 1978.

Kowalczk, A. and Froelich, P.: Cave air ventilation and $\mathrm{CO}_{2}$ outgassing by radon-222 modeling: how fast do caves breathe? Earth Planet. Sci. Lett., 289, 209-219, 2010.

Krivonogov, S. K., Takahara, H., Kuzmin, Y. V., Orlova, L. A., Jull, A. J. T., Nakamura, T., Miyoshi, N., Kawamuro, K., and Bezrukova, E. V.: Radiocarbon chronology of the late Pleistocene-Holocene paleogeographic events in Lake Baikal region (Siberia), Radiocarbon, 46, 745-754, 2004.

Lambert, W. and Aharon, P.: Controls on dissolved inorganic carbon and $\delta^{13} \mathrm{C}$ in cave waters from DeSoto Caverns: Implications for speleothem $\delta^{13} \mathrm{C}$ assessments. Geochim. Cosmochim. Acta, 75, 753-768, 2011.

Lau, Y. L. and Liu, D.: Effect of flow rate on biofilm accumulation in open channels, Wat. Res., 27, 355-360, 1993.

Lee, C., McKenzie, J. A., and Sturn, M.: Carbon isotope fractionation and changes in flux and composition of particulate matter resulting from biological activity during a sediment trap experi- ment in Lake Greifen, Switzerland, Limnol. Oceanogr., 32, 8396, 1987.

Léveillé, R. J., Fyfe, W. S., and Longstaffe, F. J.: An unusual occurrence of Ca-Mg-carbonate-silicate speleothems in basaltic caves, Kauai, Hawaii, J. Geology, 108, 613-621, 2000a.

Léveillé, R. J., Fyfe, W. S., and Longstaffe, F. J.: Geomicrobiology of carbonate-silicate microbialites from Hawaiian basaltic sea caves, Chem. Geology, 169, 339-355, 2000b.

Léveillé, R. J., Fyfe, W. S., and Longstaffe, F. J.: An isotopic and geochemical study of carbonate-clay mineralization in basaltic sea caves: abiotic versus microbial processes, Geobiology, 5, 235-249, 2007.

Luther I. and George W.: Pyrite oxidation and reduction: Molecular orbital theory considerations, Geochimica et Cosmochimica Acta, 51, 3193-3199, 1987.

Mattey D., Lowry, D., Duffet, J., Fisher, R., Hodge, E., and Frisia, S.: A 53 year seasonally resolved oxygen and carbon isotope record from a modern Gibraltar speleothem: reconstructed dripwater and relationship to local precipitations, Earth Plant. Sci. Lett., 269, 80-95, 2008.

Melim, L. A., Shinglman, K. M., Boston, P. J., Northup, D. E., Spilde, M. N., and Queen, J. M.: 2001. Evidence for microbial involvement in pool finger precipitation, Hidden Cave, New Mexico, Geomicrobiol. J., 18, 311-329, 2001.

Melim, L. A., Liescheidt, R., Northup, D. E., Spilde, M. N., Boston, P. J., and Queen, J. M.: A biosignature suite form cave pool precipitates, Cottonwood Cave, New Mexico, Astrobiology, 9, 907917, 2009.

Mickler, P. J., Banner, J. L., Stern, L., Asmerom, Y., Edwards, R. L., and Ito, E.; Stable isotopic variations in modern tropical speleothems: Evaluating applications to paleoenvironmental reconstructions, Geochimica et Cosmochimica Acta, 68, 43814393, 2004.

Moses C. O., Kirk Nordstrom D., Herman J. S., and Mills A. L.: Aqueous pyrite oxidation by dissolved oxygen and by ferric iron, Geochimica et Cosmochimica Acta, 51, 1561-1571, 1987.

Mühlinghaus, C., Scholz, D., and Mangini, A.: Modelling stalagmite growth and $\delta^{13} \mathrm{C}$ as a function of drip interval and temperature, Geochimica et Cosmochimica Acta, 71, 2780-2790, 2007.

Mühlinghaus, C., Scholz, D., and Mangini, A.: Modelling fractionation of stable isotopes in stalagmites, Geochimica et Cosmochimica Acta, 73, 7275-7289, 2009.

Mulec, J., Kosi, G., and Vrhovsek, D.: Algae promote growth of stalagmites and stalactites in karst caves (Skocjanske jame, Slovenia), Carbonates and Evaporites, 22, 6-9, 2007.

Murray, J. W.: Iron oxides, in: Marine minerals, Mineralogical Society of America, edited by: Burns, R. G., Washington, DC, 47-98, 1979.

Northup, D. E. and Lavoie, K.: Geomicrobiology of Caves: A Review, Geomicrobiol. J., 18, 199-222, 2001.

Northup, D. E., Barns, S. M., Yu, L. E., Spilde, M. N., Schelble, R. T., Dano, K. E., Crossey, L. J., Connolly, C. A., Boston, P. J., Natvig, D. O., and Dahm, C. N.: Diverse microbial communities inhabiting ferromanganese deposits in Lechuguilla and Spider Caves, Environ. Microbiol., 5, 1071-1086, 2003.

Northup, D. E., Dahm, C. N., Melim, L. A., Spilde, M. N., Crossey, L. J., Lavoie, K. H., Mallory, L., Boston, P. J., Cunningham, K. I., and Barns, S. M.: Evidence for geomicrobiological interac- 
tions in Guadalupe (NM) Caves, J. Cave Karst Studies, 62, 8090, 2000.

Odintsev M. M. and Serikov A. P.: Industrial perspectives of the Lensk copper sandstone deposits. Essay on the geology and raw materials in Eastern Siberia, Irkutsk, Irkutsk Oblastnoe Isdatel'stvo, 26-28, 1947 (in Russian).

Onac, B. P.: Mineralogy of speleothems from caves in the Padurea Craiului Mountains (Romania), and their palaeoclimatic significance, Cave Karst Sci., 23, 109-124, 1996.

Oster, J., Montanez, I., Guilderson, T., Sharp, W., and Banner, J.: Modeling speleothem $\delta^{13} \mathrm{C}$ variability in a central Sierra Nevada cave using ${ }^{14} \mathrm{C}$ and ${ }^{87} \mathrm{Sr} /{ }^{86} \mathrm{Sr}$, Geochim. Cosmochim. Acta, 74, 5228-5242, 2010.

Pacton, M., Ariztegui, D., Wacey, D., Kilburn, M. R., Rollion-Bard, C., Farah, R., and Vasconcelos, C.: Going nano: a new step towards understanding the processes governing freshwater ooid formation, Geology, 40, 547-550, 2012.

Paull, C. K., Neumann, A. C., Bebout, B., Zabielski, V., and Showers, W.: Growth rate and stable isotopic character of modern stromatolites from San Salvados, Bahamas, Palaeoecology, 95, 335344, 1992.

Peck, S. B.: Bacterial deposition of iron and manganese oxides in North American caves, Natil. Speleol. Soc. Bull., 48, 26-30, 1986.

Pellerin, A., Lacelle, D., Fortin, D., Clark, I. D., and Lauriol, B.: Microbial diversity in endostromatolites (cf. fissure calcretes) and in the surrounding permafrost landscape, Haughton impact structure region, Devon Island, Canada, Astrobiology, 9, 807-822, 2009.

Petryshyn, V. A., Corsetti, F. A., Berelson, W. M., Beaumont, W., and Lund, S. P.: Stromatolite lamination frequency, Walker Lake, Nevada: Implications for stromatolites as biosignatures, Geology, 40, 499-502, 2012.

Polyak, V. J. and Cokendolpher, J. C.: Recovery of microfossils from carbonate speleothems, Natl. Speleolog. Soc. Bull., 54, 6668, 1992.

Polyak, V. J. and Cokendolpher, J. C.: Recovery of microfossils from carbonate speleothems, NSS Bull., 54, 66-68, 1992.

Rollion-Bard, C. and Marin-Carbonne, J.: Determination of SIMS matrix effects on oxygen isotopic compositions in carbonates, $\mathrm{J}$. Analyt. Atom. Spectrom., 26, 1285-1289, 2011.

Rollion-Bard, C., Mangin, D., and Champenois, M.: Development and application of oxygen and carbon isotopic measurements of biogenic carbonates by ion microprobe, Geostandards Geoanalyt. Res., 31, 39-50, 2007.

Rossi, C., Lozano, R. P., Isanta, N., and Hellstrom, J.: Manganese stromatolites in caves: El Soplao (Cantabria, Spain), Geology, 38, 1119-1122, 2010.
Sand, W.: Microbial mechanisms of deterioration of inorganic substrates - A general mechanistic overwiew, Internat. Biodeteior. Biodegrad., 40, 183-190, 1997.

Santschi, P. H., Guo, L., Means, J. C., and Ravichandran, M.: Natural organic matter binding of trace metal and trace organic contaminants in estuaries. in: Biogeochemistry of Gulf of Mexico Estuaries, edited by: Bianchi, T. S., Pennock, J. R., and Twilley, R., Wiley, New York, 347-380, 1998.

Sanz-Montero, M. E., Rodriguez-Aranda, J. P., and Garcia del Cura, M. A.: Dolomite-silica stromatolites in Miocene lacustrine deposits from the Duero Basin, Spain : the role of organotemplates in the precipitation of dolomite, Sedimentology, 55, 729-750, 2008.

Schippers, A. and Jorgensen, B. B.: Oxidation of pyrite and iron sulfide by manganese dioxide in marine sediments, Geochimica et Cosmochimica Acta, 65, 915-922, 2001.

Schwertmann, U. and Taylor, R. M.: Iron oxides, in: Minerals in soil environments, edited by: Dixon, J. B. and Weed, S. B., Soil Science Society of America, Madison, Wis, 145-180, 1977.

Spilde, M. N., Northup, D. E., Boston, P. J., Schelble, R. T., Dano, K. E., Crossey, L. J., and Dahm, C. N.: Geomicrobiology of Cave Ferromanganese Deposits: A Field and Laboratory Investigation, Geomicrobiol. J., 22, 99-116, 2005.

Spötl, C., Fairchild, I. J., and Tooth, A. F.: Cave air control on dripwater geochemistry, Obir Caves (Austria): Implications for speleothem deposition in dynamically ventilated caves, Geochimica et Cosmochimica Acta, 69, 2451-2468, 2005.

Tebo, B. M., Ghiorse, W. C., van Waasbergen, L. G., Siering, P. L., and Caspi, R.: Bacterially mediated mineral formation: insights into manganese (II) oxidation from molecular genetic and biochemical studies, Rev. Mineral., 35, 225-266, 1997.

Tremaine, D. M., Froelich, P. N., and Wang, Y.: Speleothem calcite farmed in situ: Modern calibration of $\delta^{18} \mathrm{O}$ and $\delta^{13} \mathrm{C}$ paleoclimate proxies in a continuously-monitored natural cave system, Geochimica et Cosmochimica Acta, 75, 4929-4950, 2011.

Vaks, A., Gutareva, O. S., Breitenbach, S. F. M., Avirmed, E., Mason, A. J., Thomas, A. L., Osinzev, A. V., Kononov, A. M., and Henderson, G. M.: Speleothems reveal $500000-$ year history of Siberian permafrost, Science, 340, 183-186, doi:10.1126/science.1228729, 2013.

Vasconcelos, C., McKenzie, J. A., Bernasconi, S., Grujic, D., and Tien, A. J.: Microbial mediation as a possible mechanism for natural dolomite formation at low temperatures, Nature, 377, 220 222,1995 